\title{
Courting Genocide: The Unintended Effects of Humanitarian Intervention
}

\author{
Jide Nzelibe $\dagger$
}

\section{INTRODUCTION}

"Never Again." This pithy and evocative phrase, which conjures up horrific images of the Holocaust and other German atrocities committed during World War II, has long been the rallying call for those advocating a more robust international legal regime to combat humanitarian atrocities. ${ }^{1}$ Today, the belief that perpetrators of atrocities should no longer be able to hide behind the shield of state sovereignty has gained widespread currency. ${ }^{2}$ Indeed, the

\section{Copyright $\mathbb{C} 2009$ California Law Review, Inc. California Law Review, Inc. (CLR) is a} California nonprofit corporation. CLR and the authors are solely responsible for the content of their publications.

$\dagger$ Professor of Law, Northwestern University Law School. For helpful comments and discussions, I would like to thank William Alford, Scott Anderson, Ronen Avraham, Kenworthey Bilz, Kristen Boon, Margaret Brinig, Adam Cox, Timothy Crawford, Nicole Garnett, Tom Ginsburg, Ryan Goodman, Robert Hockett, Michael Kang, Eugene Kontorovich, Alan Kuperman, Richard McAdams, Jonathan Masur, Martha Nussbaum, Mary Ellen O'Connell, Ariel Porat, Eric Posner, Jaya Ramji-Nogales, Adam Samaha, Max Schanzenbach, Peter Spiro, Lior Strahlevitz, David Weisbach, John Yoo and workshop participants at Harvard Law School, Cornell Law School, Michigan State University Law School, Notre Dame Law School, Temple University Law School, University of Virginia Law School, and the University of Chicago Law School. Daniel Nash and Alice Park provided valuable research assistance.

1. See Universal Declaration of Human Rights, G.A. Res. 217A, at 71, U.N. GAOR, 3d Sess., 1st plen. mtg., U.N. Doc. A/810 (Dec. 12, 1948); Convention on the Prevention and Punishment of the Crime of Genocide, Dec. 9, 1948, 102 Stat. 3045, 78 U.N.T.S. 277 [hereinafter Genocide Convention]; Martin Cook, Ethical and Legal Dimensions of the Bush "Preemption" Strategy, 27 Harv. J.L. \& Pub. Pol'y 797, 803 (2005) ("Rallied by the slogan 'Never Again!', individual states and the newly created United Nations began generation of an entire body of international humanitarian law, beginning with The Universal Declaration of Human Rights and the Genocide Convention, which cumulatively restricted (at least on paper) the absolute scope of state sovereignty.").

2. See The Secretary-General, Report of the Secretary-General on the Work of the Organization, U.N. GAOR, 46th Sess., Supp. No. 1, at 10, U.N. Doc. A/46/1 (1991) ("It is now increasingly felt that the principle of non-interference with the essential domestic jurisdiction of States cannot be regarded as a protective barrier behind which human rights could be massively or systematically violated with impunity."); Fernando Teson, Humanitarian InTERventTION: AN INQUIRY INTO LAW AND MORALITY 5-12 (1997) (summarizing normative arguments for humanitarian intervention); SEAN D. MurPhy, Humanitarian InTERVEnTION: The United Nations in an Evolving World ORder 202-12 (1996) (making the same argument); David 
emerging international legal norm of the "responsibility to protect" suggests that the international community has an affirmative obligation to intervene in order to prevent atrocities in states that are themselves unwilling or unable to do so. ${ }^{3}$ Advocates of this legalistic approach tend to rely loosely on analogies between a global regime of humanitarian intervention and the United States' own domestic framework of tort law and criminal law, with its attendant objectives of deterrence, incapacitation, and restoration of victims. ${ }^{4}$ Over the past decade, acts of genocide or mass atrocities have fuelled calls for humanitarian interventions in the Balkans, Rwanda, Burma, Burundi, Liberia, Sierra Leone, Congo, and the Darfur region of Sudan.

While the imagery of the Holocaust as a clarion call for humanitarian intervention is compelling, this Article argues that it has helped spawn an international legal regime that might have perverse effects. The problem is that unlike the Holocaust, most contemporary atrocities take place in the context of full-blown civil wars or rebellions in which rebel leaders are usually pursuing independent political objectives that might be more valuable to them than the lives of their followers. Herein lies the paradox: because humanitarian interventions tend to increase the chance that rebel leaders are going to achieve

Scheffer, Towards a Modern Doctrine of Humanitarian Intervention, 23 U. TOL. L. REv. 253, 258-59 (1992) (providing normative justifications for a collective regime of humanitarian intervention).

3. Secretary-General's High-Level Panel on Threats, Challenges and Change, $A$ More Secure World: Our Shared Responsibility, $\uparrow 203$, delivered to the General Assembly, U.N. Doc. A/59/565 (Dec. 2, 2004) [hereinafter High Level Report] (discussing the contours of the responsibility to protect); INT'L COMm'N ON INTERvention \& STATE SOVEREIGNTY, The RESPONSIBILITY to PROTECT paras. 6.30-.40 (2001), available at http://www.iciss.ca/pdf/ Commission-Report.pdf [hereinafter ResponsibILITY To PROTECT] (describing the same responsibility); see also Christopher C. Joyner, "The Responsibility to Protect": Humanitarian Concern and the Lawfulness of Armed Intervention, 47 VA. J. INT'L L. 693, 716, 723 (2007) (referring to the responsibility to protect as an emerging international legal norm); Anne-Marie Slaughter, Security, Solidarity, and Sovereignty: The Grand Themes of the U.N. Reform, 99 AM. J. INT'L L. 619, 620 (2005) ("[The 2005 High Level Panel Report] endorsed the 'responsibility to protect'- the idea that the international community has a right and a duty to intervene in states that cannot or will not protect the human rights of their people against 'genocide and other largescale killing,' ethnic cleansing or serious violations of international humanitarian law.").

4. See High Level Report, supra note 3, para. 201 ("[T] here is a growing acceptance that while sovereign Governments have the primary responsibility to protect their own citizens from such catastrophes, when they are unable or unwilling to do so that responsibility should be taken up by the wider international community-with it spanning a continuum involving prevention, response to violence, if necessary, and rebuilding shattered societies."); Dino Kritsiotis, Reappraising Policy Objections to Humanitarian Interventions, 19 Mich. J. INT'L L. 1005, 1016 n.32 (1998) ("[G]eneral considerations of humanity, and possibly even the deterrence of acts of internal aggression and repression, are powerful forces behind policy-based arguments which suggest the need for an acceptance of some form of humanitarian intervention."); see also Fernando R. Teson, The Liberal Case for Humanitarian Intervention, in Humanitarian Intervention: Ethical, Legal and Political Dilemmas 93-95 (J.L. Holzgrefe \& Robert O. Keohane eds., 2003) (arguing that the international community's duty to intervene encompasses the obligations to rescue victims from tyranny if such intervention can be done at a reasonable cost). 
their preferred political objectives, rebel leaders might have an incentive to engage in the kinds of provocative actions that make atrocities against their followers more likely in the first place. In other words, by creating more uncertainty about the distribution of resolve and costs among the combatants, a legalistic humanitarian intervention approach might perversely spawn a vicious cycle of even greater atrocities.

This Article illustrates the perverse logic of humanitarian interventions by exploring two contemporary cases: Sudan (Darfur) and Kosovo. While these case studies are by no means exhaustive, they are representative of the kinds of civil wars in which mass atrocities are likely to take place. Together, these case studies reveal a consistent pattern. First, rebel or victim leaders engage in provocative actions against a dominant group largely (or partly) because they hope to attract humanitarian intervention against the dominant group. The dominant group then responds by aggressively committing even more atrocities against the victim group. In the end, however, the humanitarian intervention either does not come or comes too late to prevent the bulk of the atrocities from happening.

Traditionally, the question of how humanitarian interventions affect the commission of atrocities has been answered by reference to both the motivation of the intervening party and the sovereignty costs imposed on the target of intervention. ${ }^{5}$ Thus, much of the legal and philosophical scholarship on humanitarian intervention is devoted to designing institutional frameworks for screening out pretextual humanitarian interventions from well-motivated ones. ${ }^{6}$ However, much of this literature assumes that well-motivated humanitarian interventions will have benign effects. ${ }^{7}$ Recently, a number of political scientists have begun to question this conventional wisdom regarding the interaction between humanitarian interventions and mass atrocities. ${ }^{8}$ In this picture, because outside intervention during a humanitarian crisis is likely to bias the outcome of the dispute in favor of the rebel group that is the target of the atrocities, some political scientists have argued that rebel groups might rationally gamble on humanitarian intervention by provoking the dominant group to commit atrocities. ${ }^{9}$ Such accounts often stress the fact that humanitarian interventions suffer from the same pathologies as fraudulent insurance schemes because they create moral hazard by encouraging risktaking among the intended beneficiaries.

But these rational "moral hazard" explanations are somewhat incomplete or under-theorized. For instance, these models do not explain why the dominant group and the rebels would be incapable of reaching mutually beneficial
5. See infra Part I.A.
6. See id.
7. See infra text accompanying notes $12-20$.
8. See infra Part I.B.
9. See id. 
bargains that avoid the costs of genocidal violence in the first place. After all, if humanitarian intervention gives an edge to rebel groups and their political agendas, we would expect that it would simply increase the rebels' bargaining leverage vis-à-vis the dominant group without necessarily increasing the chance of a war with genocidal consequences. Furthermore, these models often assume a seemingly unrealistic empirical picture of rebel behavior where rebels are willing to subject themselves to genocidal violence in order to increase the chance (perhaps only marginally) that they will achieve political objectives such as territorial concession or self-determination. Indeed, one might argue that according to the same logic, victims in a domestic setting ought to have an incentive to instigate crimes or torts against themselves in order to increase the chance that the state might prosecute or seek restitution from those who wronged them. Finally, the simple moral hazard story does not account for why dominant groups would choose genocidal violence rather than a more targeted form of violence to achieve their military objectives.

This Article suggests an alternative rationalist explanation for why the prospect of outside humanitarian intervention leads to bargaining breakdowns between rebel groups and dominant groups, which might perversely increase the chance of mass atrocities occurring. First, the prospect of humanitarian intervention often increases the level of uncertainty about the distribution of costs and resolve between the combatants. In turn, such uncertainty amplifies the possibility of divergent expectations between the dominant and rebel group regarding the outcome of a civil war. Moreover, efficient bargaining is also hampered because the dominant group cannot credibly identify the "true" rebels with whom it should bargain. Second, the basic bargaining model is complicated by the fact that there is often a principal-agent problem between rebel leaders and non-rebel members of the target group (the minority group targeted by the dominant group). Simply put, rebel leaders might often engage in high-risk rebellions with remote chances of humanitarian intervention because they reap most of the benefits of such interventions, while non-rebel members of the target group bear the brunt of genocidal reprisals by the dominant group. Third, and finally, a state might choose to engage in an inefficient war against a rebel group in order to signal to future rebels that it is a hard bargainer. Such a dynamic is especially likely when the perpetrator is a regime in a weak state where there is a high likelihood of multiple challenges by other prospective rebel groups. Thus, a dynamic that might seem inefficient in the short run might actually be rational from a long-run perspective.

One consequence of this framework is that it helps resolve the empirical puzzle related to why rebel leaders might subject their followers to the risks of genocidal violence just to increase the chances of achieving certain political objectives. There are three reasons why such a high-risk strategy might be logical in a humanitarian crisis surrounding a civil war, but perhaps illogical in a domestic criminal or torts context. First, in a humanitarian crisis, the actual 
victims who are harmed by a campaign of mass atrocities are usually distinct from the rebel leaders who stand to benefit the most from humanitarian interventions. By contrast, in the domestic corrective justice context, there is usually some symmetry between the individuals injured and the individuals who stand to benefit from any compensation scheme that addresses such injuries. ${ }^{10}$ Second, under the domestic law of torts, a victim who does not take reasonable precautions to prevent an injury to himself might be barred from recovery altogether or have his recovery reduced based on comparative fault principles. ${ }^{11}$ But in a humanitarian intervention framework, there is no formal mechanism for reducing relief to rebel leaders who do not take adequate precautions to avoid atrocities. Third, and most importantly, the goal of our domestic corrective justice framework is to restore the status quo ex ante for the victim, but humanitarian interventions generally tend to place leaders of rebel groups in a better position than the status quo ex ante. ${ }^{12}$

The motivation of rebel leaders only tells half the story. One might wonder why perpetrators of mass atrocities who belong to dominant groups would allow themselves to be pawns in a strategic ploy by rebel leaders to instigate humanitarian interventions. While perpetrating atrocities to quell rebellions might not necessarily be an optimal strategy, it is hardly an irrational one. Leaders of dominant groups usually perpetrate such atrocities as a secondbest response to high-stakes rebellions. In other words, where outright military victory or targeted violence against rebel groups might not be available options due to resource or political constraints, leaders of dominant groups will tend to use the threat of indiscriminate violence to coerce the rebel leaders to abandon their political demands.

This Article proposes a comparative fault approach to humanitarian interventions to address the moral hazard problems identified above. Under this approach, the benefits that rebel leaders obtain from humanitarian interventions would be reduced if they are found to have engaged in provocative behavior. Typically, peace settlements negotiated in the wake of humanitarian interventions purport to resolve the root causes of civil conflicts by accommodating some of the rebels' political demands. The problem is that when the international community intervenes in a civil war and attempts to restructure the domestic political environment by forcing or encouraging the combatants to share political power, the rebel leaders are often given leverage that they would not ordinarily have absent humanitarian intervention. And it is this latter factor that partly motivates the perverse dynamic that leads rebel leaders to initiate suicidal rebellions in the first place. Alternatively, another strategy is to impose lustration policies against rebel leaders who have engaged in provocative behavior against dominant groups. Finally, reducing the

10. See infra text accompanying notes $26-30$.

11. See id.

12. See id. 
sanctions faced by perpetrators of atrocities would also reduce the intervention benefits enjoyed by rebel groups. In sum, this Article concludes that the optimal regime of humanitarian intervention would be less, and not more robust, than the status quo.

Part I first explores some of the assumptions about the potential effects of humanitarian intervention in the existing legal literature and questions some of the comparisons to the domestic corrective justice and criminal enforcement regimes. By highlighting some of the differences between a regime of humanitarian intervention and domestic criminal law or tort law, this Part suggests that the prevailing assumption that greater investment in enforcement will necessarily cause a decline in atrocities is both mistaken and unrealistic. Part I.B discusses and criticizes the political science literature on the relationship between humanitarian interventions and mass atrocities. Part II, as a whole, presents a framework for how humanitarian intervention likely affects the behavior of both perpetrators and victims in a full-blown civil war or rebellion. More specifically, this Part explores how the decisions of the international community often interact with the decisions of perpetrators and victims to produce unintended consequences in a significant number of civil wars involving mass atrocities. Part III briefly illustrates this perverse dynamic with case studies from Kosovo and Sudan (Darfur). Parts IV and V build on Parts II and III to explore some empirical implications of the framework; they also make normative recommendations that might mitigate some of the perverse effects of a global humanitarian intervention regime.

One caveat: while the interaction between humanitarian interventions and mass atrocities might be quite complex, this Article does not argue that the net effects of humanitarian interventions are perverse. However, any empirical assumptions that such effects are likely to be benign is also unfounded. In any event, the more relevant utilitarian question is whether we can modify the current humanitarian intervention regime to reduce any perverse effects.

\section{I}

\section{LITERATURE OVERVIEW}

Mirroring the goals of the corrective justice framework of criminal and tort law in the United States, many, if not most, international legal commentators believe that "well-motivated" humanitarian interventions will both force perpetrators of atrocities to internalize the costs of their crimes and also make victims whole. Indeed, to the extent that the legal literature discusses humanitarian interventions' possible counterproductive effects, it tends to focus on the risks imposed by third parties who engage in forceful military actions on pretext. Part I.A suggests that the goals and mechanisms of criminal law and bilateral corrective justice, which make sense in the domestic realm, do not necessarily translate well to the international regime governing humanitarian atrocities. Part I.B then critically examines the political science literature on the 
relationship between mass atrocities and humanitarian interventions.

\section{A. The Legal Conventional Wisdom}

The justifications for the humanitarian and intervention regime in the legal literature are deeply wedded to the same ideals of bilateral corrective justice and criminal enforcement in the U.S. legal system. Generally, the objectives of corrective justice and retribution in a domestic setting are accomplished by both criminal law and tort law. Criminal law focuses for the most part on sanctioning perpetrators, whereas tort law focuses largely on compensating victims for their injuries and forcing perpetrators to internalize the economic costs of their wrongful conduct.

Like its American counterpart, the global regime targeting mass atrocities assumes that in each situation there is a clearly delineated perpetrator and a victim who has been injured by the perpetrator's actions. ${ }^{13}$ To be clear, third party interventions in the wake of civil wars of humanitarian crisis may also serve a range of other goals that are not connected to dispensing justice. ${ }^{14}$ But the global regime of forcible humanitarian interventions that targets atrocities generally assumes that the perpetrator has to be stopped or deterred and the victim restored, at least to the extent possible. Based on this understanding, proponents of the global justice approach believe that the imposition of a more robust humanitarian intervention regime that targets perpetrators and restores victims will lead to an overall decline in the number of humanitarian atrocities that occur. 15 Indeed, the emerging international legal norm of "the

13. For instance, the International Commission Report of the Responsibility to Protect includes as the goals of humanitarian intervention not only prevention of genocides, but also making reparations to the victims and reaching a solution to the underlying conflict. See RESPONSIBILITY to Protect, supra note 3, para. 4.19 (suggesting that military intervention would be justified to avert large scale loss of life or large-scale ethnic cleansing); see also id. para. 5.1 (discussing the other objectives of rebuilding the society and restoring victims); Teson, supra note 4, at 93-95 (focusing on the international community's responsibility to rescue victims from humanitarian harm). Similarly, the establishment of the International Criminal Court under the Rome Treaty has also been justified under deterrent, rehabilitative, and retributivist grounds. See Allison Marston Danner, Enhancing the Legitimacy and Accountability of Prosecutorial Discretion at the International Criminal Court, 97 AM. J. INT'L L. 510, 543 (2003) (observing that international criminal tribunals combine a retributive and deterrent approach); see also Diane Marie Amann, Group Mentality, Expressivism, and Genocide, 2 InT'L CrIM. L. Rev. 93, 118-20 (2002) (focusing on expressivist rationale for international criminal tribunals); $M$. Cherif Bassiouni, Combating Impunity for International Crimes, 71 U. CoLo. L. REv. 409, 410 (2000) ("The pursuit of justice and accountability, it is believed, fulfills fundamental human values, helps achieve peace and reconciliation, and contributes to the prevention and deterrence of future conflicts."); David J. Scheffer, War Crimes and the Crimes Against Humanity, 11 PACE INT'L L. REv. 319, 328 (1999) ("As instruments of deterrence, the tribunals are formidable partners that cannot be lightly ignored in the future.").

14. For a concise discussion of the myriad of roles served by the international community in the aftermath of war or crisis, see Kristen E. Boon \& Phillip M. Moremen, Foreword: When the Fighting Stops, 38 Seton Hall L. Rev. 1233 (2008).

15. See Bassiouni, supra note 13, at 328; see also Payam Akhavan, Beyond Impunity: Can International Criminal Justice Prevent Future Atrocities?, 95 AM. J. INT'L L. 7, 16 (2001) 
responsibility to protect" suggests that states have an affirmative obligation to intervene to prevent mass atrocities in other states and to help resolve the underlying problems that prompted the atrocities in the first place. ${ }^{16}$

The argument that a more robust humanitarian intervention regime is an appropriate response to atrocities can be criticized on sovereignty-related grounds, including the claim that third parties might use intervention as a pretext to start wars for reasons unrelated to preventing atrocities. ${ }^{17}$ This Article brackets this objection and assumes for now, consistent with recent literature supporting humanitarian interventions, that a nonpretextual humanitarian regime is not only feasible, but that greater media coverage of wars and recent international legal developments have amplified the costs of pretextual interventions. ${ }^{18}$ Indeed, one of the rationales for trying to institutionalize the humanitarian intervention regime within the United Nations framework is to ensure that the obligation to intervene will be implemented consistently and uniformly, and not used by the intervening parties as a tool to achieve other goals. ${ }^{19}$ More importantly, the possibility that states might act for nonaltruistic reasons should not necessarily undermine the legality of humanitarian interventions because states that act for selfish reasons can presumably produce normatively desirable humanitarian outcomes. ${ }^{20}$ In any event, the segment of the legal academy that embraces a more robust regime of humanitarian intervention assumes intervention might accomplish some of the same goals as a domestic enforcement regime; simply put, more enforcement will result in

(discussing the deterrent effects of international tribunals). The victim-centered perspective looms large in the legal literature on humanitarian atrocities. For instance, some commentators have even argued that victims have a right to actively resist genocide by military means - a right which the international community ought to respect. See David Kopel, Is Resisting Genocide a Human Right, 81 Notre Dame L. Rev. 1275 (2006).

16. See Responsibility to PRotect, supra note 3, paras. 4.19, 5.1.

17. See Ryan Goodman, Humanitarian Intervention and Pretexts for War, 100 AM. J. INT'L L. 107, 108-09 (2006) (discussing the extensive literature that alludes to the dangers of pre-textual humanitarian interventions); Thomas Lee, The Augustinian Just War Tradition and the Problem of Pretext in Humanitarian Intervention, 28 FordHAM INT'L L.J. 756 (2005) (same); Thomas M. Franck, Recourse to Force: State Action Against Threats and Armed Attacks 172, 185-86 (2002) (suggesting that states could use unilateral humanitarian interventions for self serving purposes); Louis Henkin, How Nations Behave: Law and Foreign Policy 144-45 (2d ed. 1979) ("' $[$ H]umanitarian intervention' can too readily be used as the occasion or pretext for aggression.").

18. See Goodman, supra note 17 , at 110 ("[T]he very conditions that commentators suggest would unleash pretext wars by aggressive states may, in general and on average, temper the bellicose behavior of those states.").

19. See Oscar Schachter, International Law in Theory and Practice, 123-25 (1991).

20. See Phillip Bobbitt, What's in it for US?, Guardian (London), June 7, 2003, at 21 ("This demand-that a state's motives be purely self-sacrificing or are otherwise discreditablereflects expectations that are so unrealistic as to be counterproductive to humanitarian goals. Instead, we should be devising doctrines ... that clearly state how the intersection of strategic interests, measured on a global scale, with humanitarian interests can move states in the right direction."). 
fewer atrocities. ${ }^{21}$

But let us examine closely this analogy between the role of the international community in the global intervention regime and that of a lawenforcer in a domestic context. For a robust enforcement regime to work, it must be able to control wrongdoing in some systematic and predictable way. In the domestic criminal enforcement setting, the decision and resolve of the state to prosecute a crime is always assumed to be a one-sided affair; thus, while the state is supposed to influence the perpetrator's decision to commit crimes or the victim's decision to avoid crimes, neither the perpetrator nor the victim is supposed to be capable of influencing the state's decision to prosecute crimes. ${ }^{22}$ For instance, when considering whether to prosecute a particular crime in the domestic framework, the state does not ordinarily have to consider whether a perpetrator will commit more crimes against a victim or threaten harm against the state itself. Nor does the state in the domestic law enforcement context ever concern itself with the possibility that victims might provoke crimes against themselves in order to benefit from prosecutions against a perpetrator. Of course, a victim in the domestic setting might get some vindictive pleasure from seeing the perpetrator of a crime against her punished, ${ }^{23}$ but there is no reason to assume that such benefits will ever outweigh the injuries suffered by the victim. Thus, the risk that a domestic law enforcement framework might create any perverse or unintended consequences is trivial, if not nonexistent.

The international community's resolve and decision making in a humanitarian intervention context works somewhat differently. Unlike a law enforcement agent in a domestic setting, the decision of the international community or third parties to conduct humanitarian interventions influences, and is influenced by, the decisions of both the victims and the perpetrators of atrocities. But the problem is that the objectives of both the perpetrators and the victims in influencing humanitarian interventions are likely to be inconsistent with the international community's goal of reducing atrocities. This dynamic makes it very difficult in many contexts to determine whether the decision to intervene will result in a net reduction of atrocities.

To understand how interdependent decision making in the humanitarian context complicates the traditional law enforcement model, let us examine how the international community's decision might interact with that of the combatants. Take the perpetrator of atrocities, for instance. The international community's decision to intervene is often a function of its subjective belief

21. See sources cited infra notes 15-17.

22. This assumption is subject to some minor qualifications. For instance, some commentators have observed that criminals can invest more in anti-detection strategies once the state increases it enforcement efforts. See Chris William Sanchirico, Detection Avoidance, 81 N.Y.U. L. REV. 1331, 1338-39 (2006).

23. See Jeremy Bentham, Principles of Morals and Legislation $171 \mathrm{n} .1$ (Hafner Publ'g Co. 1961) (1781) ("Satisfaction thus administered to a party injured . . may be styled a vindictive satisfaction ...."). 
regarding the intervention's potential for success and its potential costs, ${ }^{24}$ but both of these factors are influenced directly by the resolve and military resources of the perpetrator. ${ }^{25}$ Moreover, rebel leaders can also influence the international community's decision to intervene. In the political environment governing humanitarian interventions, politicians in third-party states might be subject to electoral punishment by their domestic constituencies for seeming too reluctant to use military force to end hostilities and resolve the underlying conflicts. ${ }^{26}$ Rebel leaders might exploit this dynamic by engaging in provocative actions that are more likely to escalate the hostilities and hence increase the political demand for intervention by domestic audiences in thirdparty states.

Of course, one might argue that like victims in a domestic torts context, the victims of humanitarian atrocities already internalize the costs of any provocative behavior. But there are three fundamental differences between how international humanitarian and domestic torts regimes influence the incentives of victims. Collectively, these differences make it unlikely that victims in a humanitarian intervention context will have the same incentives as victims in a domestic context to take appropriate precautions to avoid injuries; indeed, in the context of a humanitarian crisis these differences might even create perverse incentives for victims (or rebel leaders) to avoid such precautions.

First, in the current humanitarian regime governing atrocities, the primary beneficiaries of humanitarian intervention are usually the rebel leaders rather than the individual victims themselves. This asymmetric remedial scheme is driven by the simple logic that the international community cannot realistically negotiate a cessation of hostilities with all the victims in a humanitarian crisis, and so the international community has to rely on the demands of rebel leaders as a second-best proxy for what the victims want. In the domestic corrective justice context, by contrast, it is the injured victim who stands to benefit from any compensation scheme tailored to address their injuries. ${ }^{27}$

24. Patrick M. Regan, Conditions of Successful Third-Party Intervention in Intrastate Conflicts, 40 J. CoNFL. REs. 336, 347-48 (1996) (discussing factors that influence successful third-party interventions, such as the costs of the intervention and the level of casualties); see also Patrick M. Regan, Civil Wars and Foreign Powers 45 (2000) ("[T]hree factors can influence the expected utility of intervening: costs, utilities over outcomes, and estimates of the likelihood of achieving a successful outcome, all are intertwined.").

25. Charles Kupchan, Getting In: The Initial Stage of Military Intervention, in ForeigN Military Intervention: The Dynamics of Protracted Conflict 256 (Ariel Levite, Bruce Jentleson, \& Larry Berman eds., 1991) (observing that a third-party state will only intervene if it believes the balance of resolve is in its favor).

26. Barry M. Blechman, The Intervention Dilemma, 18 WASH. Q. 63, 64-65 (1995).

27. Indeed, as indicated by the Second Restatement of Torts, to qualify for any recovery a plaintiff must establish the existence of injury, along with the other elements of the tort, by a preponderance of the evidence. See Restatement (SECOND) of TorTs $\S 7 \mathrm{cmt}$. a ("The word 'injury' is used throughout the Restatement of this Subject to denote the fact that there has been an invasion of a legally protected interest which, if it were the legal consequence of a tortious act, would entitle the person suffering the invasion to maintain an action of tort."); RESTATEMENT 
Second, the ideal of a torts or domestic corrective justice framework is to restore the status quo ex ante for the victim, ${ }^{28}$ but humanitarian interventions generally tend to place rebel leaders in a better position than the status quo ex ante.

Third, under the domestic torts system, a victim who does not take reasonable precautions to prevent an injury might be barred from recovery altogether or have his recovery reduced based on comparative fault principles. ${ }^{29}$ But there is no formal mechanism for reducing the relief given to rebel leaders who do not take adequate precautions to avoid atrocities in a humanitarian intervention framework.

In short, in the context of a humanitarian crisis, one cannot assume that the victims, or their leaders, will have the same incentives to take precautions to avoid injury as victims in a domestic criminal context have. Yet the conventional wisdom seems to make this assumption; the rhetoric governing humanitarian interventions casts victims of atrocities as mostly harmless and vulnerable individuals who have no hand in creating their misery. ${ }^{30}$ While in practice many of the members of a rebel ethnic group might have played no direct part in an unfolding humanitarian crisis, the rebel leaders often do. But rebel leaders do not necessarily seek to maximize what is in their followers' immediate or distant welfare; indeed, like politicians elsewhere they might be more interested in securing and consolidating political power. In any event, what is absent in much of the legal literature governing humanitarian atrocities is any theory of what motivates either rebel leaders or the perpetrators of atrocities. Without such a theory, it is hard to predict what the effects of humanitarian interventions might be on the overall level of atrocities.

\section{B. The Political Science Literature}

Unlike much of the legal literature and the mainstream media, some political scientists paint a much more complicated picture of the relationship between humanitarian interventions and genocidal violence. Much of this

(SECOND) OF TORTS $\S 433 \mathrm{~B} \mathrm{cmt.} \mathrm{a} \mathrm{(observing} \mathrm{that} \mathrm{plaintiff} \mathrm{has} \mathrm{to} \mathrm{sustain} \mathrm{his} \mathrm{burden} \mathrm{of} \mathrm{proof} \mathrm{by} \mathrm{a}$ preponderance of the evidence).

28. See Moore v. Safeway, Inc., 95-1552, p. 28 (La. App. 1 Cir. 11/22/96); 700 So. 2d 831, 858 ("The primary objective of general damages is to restore the party in as near a fashion as possible to the state he was in at the time immediately preceding the injury."); see generally Restatement (SECOND) OF TORTS $\$ 903 \mathrm{cmt}$. a (1977) (noting that compensatory damages are aimed at placing victim in a "position substantially equivalent in a pecuniary way to that which he would have occupied" absent tort).

29. See Restatement (ThiRd) of TORTS: Apportionment of Liability $\S 7$ (2000) (discussing rule of comparative responsibility). Almost all American jurisdictions now follow the comparative negligence system, either through legislation or by judicial adoption. DAN B. DoBBS, LAW OF TORTS $\S 201$ (2000).

30. See M. Cherif Bassiouni, Searching for Peace and Achieving Justice: The Need for Accountability, 59 LAW \& CONTEMP. ProBs. 9, 25-26 (1996) (rejecting the notion that the victims of atrocities had a hand in their victimization). 
political science scholarship assumes, at least implicitly, that perpetrators often act rationally when they deploy genocidal violence against their weaker adversaries. ${ }^{31}$ That is, rather than acting out of a fanatical or irrational impulse to harm another ethnic group, dominant groups tend to use genocidal violence strategically in order to coerce minority rebel groups to drop their military demands. But deploying genocidal violence also tends to increase the chance of third-party humanitarian intervention against the dominant group. Thus, the crucial puzzle is why certain dominant groups deploy genocidal violence as a tactic and why certain minority groups tend to instigate "suicidal rebellions" against their more dominant adversaries.

In addressing this puzzle, certain political scientists have suggested that the role of third parties might explain why certain minority groups engage in the kinds of rebellions that are likely to spur humanitarian atrocities in the first place. For instance, Alan Kuperman has argued that intervention by the international community might unintentionally exacerbate the risks of atrocities. ${ }^{32}$ According to Kuperman, third-party intervention in the context of a humanitarian crisis operates like an insurance scheme that protects both rebels and other vulnerable individuals from the catastrophic fallout of a high-risk rebellion. ${ }^{33}$ Like government insurers who guarantee the financial stability of banks, ${ }^{34}$ the international community (or a third-party state) intervenes in part to guarantee the stability of the region in conflict and in part to prevent massive loss of life in the wake of a humanitarian crisis. But like most insurance schemes, humanitarian intervention is subject to the risk of moral hazard. ${ }^{35}$ In this framework, because rebel groups might be expecting the international community to mitigate their military disadvantages relative to the dominant group, one consequence of providing such insurance is that rebel leaders will tend to be less selective in the kinds of rebellions they initiate. ${ }^{36}$

31. See Benjamin Valentino, Final Solutions: The Causes of Genocide and Mass Killings, 9 SECuRITY Studies 1 (2000) (discussing the rationality of genocidal violence); Stathis Kalyvas, Wanton and Senseless? The Logic of Massacres in Algeria, 11 Rationality \& Soc'y 243, 245 (1999) ("[M]assacres can be understood as part of rational strategy aiming to punish and deter civilian defection under specific constraints.").

32. See Alan Kuperman, Suicidal Rebellions and the Moral Hazard of Humanitarian Intervention, in Gambling on Humanitarian InTervention: Moral Hazard, Rebellion AND Civil. WaR 1 (Timothy Crawford \& Alan Kuperman eds., 2006) [hereinafter GamBling ON HUMANITARIAN INTERVENTION].

33. See id. at 12-16; see also Timothy Crawford, Moral Hazard, Intervention, and Internal War: A Conceptual Analysis, in Gambling on Humanitarian InTER vention 26.

34. See Rauscher Pierce Refsnes, Inc. v. FDIC, 789 F.2d 313, 315 (9th Cir. 1986) ("The function of the FDIC is to help maintain the system by providing regulatory supervision over banks which it insures and by providing deposit insurance on a consistent nationwide basis. In this manner, the United States acts through the FDIC to achieve the government's goals of providing a safe and sound banking system to foster a healthy economic environment.").

35. For a detailed analysis of the moral hazard effect in insurance schemes, see Tom Baker, On the Genealogy of Moral Hazard, 75 TEx. L. Rev. 237, 250-57 (1996).

36. See Kuperman, in Gambling on Humanitarian InTERvention, supra note 32, at 14 ("The international community has sought to insure vulnerable groups against the risks of 
Although intuitively appealing, the moral hazard explanation suffers from many difficulties. First, genocidal violence in the conventional framework seems inefficient from a rational choice perspective. If the risk of humanitarian intervention favors the rebels in a high-stakes conflict, then it should presumably increase the rebels' bargaining leverage without necessarily increasing the chance of genocidal violence. ${ }^{37}$ Since genocidal violence imposes costs on both sides, there should be some peaceful settlement that all parties would prefer to war. For instance, if the expected value of intervention increases the probability that the rebels are going to achieve their ultimate military objective by 20 percent, then the dominant group should be willing to make more transfers to the rebels that reflect the rebels' increased bargaining leverage.

Second, these models often assume a seemingly unrealistic empirical picture of rebel behavior, which is that rebels are willing to subject themselves to genocidal violence in order to increase the chance (perhaps marginally) that they will achieve political objectives like territorial concessions or selfdetermination. Third, the simple moral hazard story does not account for why dominant groups would choose genocidal or indiscriminate violence, as opposed to a more targeted form of violence, to achieve their military objectives.

This Article builds on the moral hazard insights of Kuperman and others to illustrate the strategic environment in which bargaining failures between the dominant and rebel groups lead to genocidal violence. By focusing on the motivations of the various combatants in a context where they anticipate each other's responses, this Article highlights the informational and structural assumptions upon which the logic of genocidal violence depends. ${ }^{38}$

genocidal violence by establishing an emerging norm of humanitarian military intervention. In so doing, however, it has inadvertently encouraged such groups to engage in the risky behavior of launching rebellions that may provoke genocidal retaliation."). Other scholars have suggested that by reducing the costs of coordinating a rebellion, external intervention lengthens the duration of civil wars. See Ibrahim A. Elbadawi \& Nicholas Sambanis, External Interventions and the Duration of Civil Wars (World Bank Development Research Group, Working Paper No. 2433 2000), available at http://www-wds.worldbank.org/servlet/WDSContentServer/ WDSP/IB/2000/09/30/000094946_00091405494827/Rendered/PDF/multi_page.pdf.

37. See James Fearon, Rationalist Explanations for War, 49 INT'L ORG. 379, 380 (1995) ("[W]ar is costly and risky, so rational states should have incentives to locate negotiated settlements that all would prefer to the gamble of war.").

38. See id. at 380 ("A coherent rationalist for war must do more than give reasons why armed conflict might appear an attractive option to a rational leader under some circumstances-it must show why states are unable to locate an alternative outcome that both would prefer to a fight."). 
II

\section{A THEORY OF COMBATANT BEHAVIOR IN THE CONTEXT OF MASS ATROCITIES}

This Part delineates a theory of genocidal violence by expanding upon existing explanations of why certain groups rebel and why dominant groups might resort to mass atrocities to quell rebellions.

\section{A. Agency Problems and the Strategy of Rebel Leaders}

The majoritarian theory of political behavior assumes that political leaders will be faithful agents of the group they purport to represent. ${ }^{39}$ But any sophisticated analysis of rebel leaders' motivations ought to recognize that the behavior of such leaders is likely much more complicated than any conventional model of political leadership would suggest. As in the cases of Darfur and Kosovo, rebel leaders might be largely quasi-military actors or ethnic entrepreneurs who have amassed influence and power through the force of arms or through patronage; rarely do they come to their positions through the ballot box. Given the lack of both clear political accountability and any coherently defined agenda by rebel leaders, the possibility of agency drift or slippage makes it more difficult to predict whether their actions will overlap with the desires of a majority of the individuals in any of the groups they purport to represent.

Rebel leaders might seem to have very little incentive to put their followers in harm's way in a rebellion against a dominant group. But if rebel leaders rationally believe that humanitarian interventions can alter the military disadvantage the rebels face in a dispute with a dominant group, they might have an incentive to gamble on such intervention even if it comes at the cost of the lives of many members of their group. Indeed, rebel leaders might still have an incentive to engage in provocative behavior against the dominant group even if they believe the chances of intervention are slim, especially if they are gambling on intervention by a major power. ${ }^{40}$ That rebel groups often have to rely on intervention by external actors to increase their bargaining leverage explains why they might engage in provocative behavior that appears otherwise to be of little strategic value. But while such provocative behavior might eventually benefit the rebel leaders, it is not obvious that it would benefit nonrebel members of the target group, especially when the prospects of obtaining collective goods from the rebellion are low.

39. See Elizabeth Garrett, Term Limitations and the Myth of the Citizen-Legislator, 81 CORNELL L. REv. 623, 660-62 (1996) (surveying rational choice literature discussing what motivates politicians).

40. See, e.g., Timothy W. Crawford, Pivotal Deterrence: Third-Party Statecraft AND THE Pursuit OF PEACE 209 (2003) ("Because the benefits of enlisting the United States in a war may be enormous, even the slim chance of doing so may goad a party to act provocatively, become inflexible in negotiations, or otherwise do things that make wars more likely."). 
The crucial insight in this dynamic is that there might be significant divergence between the interests of rebel leaders and non-rebel members of the target group. The rebel leaders might stand to gain the lion's share of any benefits that result from humanitarian intervention, while non-rebel members of the group tend to bear the brunt of the genocidal violence inflicted by the dominant group. ${ }^{41}$ Since rebel leaders, and not non-rebels, pose the greatest threat to the dominant group, it makes sense that rebel leaders will often leverage their ability to threaten the status quo to obtain most of the political spoils and monetary benefits from a negotiated settlement to the conflict. ${ }^{42}$ Moreover, since third-party interveners tend to negotiate directly with the rebel leaders rather than other representative members of the rebel's ethnic group, the rebel leaders might often attempt to negotiate deals that benefit themselves directly rather than the target group at large, such as political offices, money, or other substantial government perks. ${ }^{43}$

To be sure, non-rebel members might occasionally obtain some benefits from a negotiated peace settlement, such as increased regional autonomy or self-determination. In other words, not all ethnic disputes will be motivated primarily or exclusively by greed or by the private interests of elites within the rebel group. But because non-rebel members are often unsure of the threat they face or which course of action will best protect their interests, rebel leaders might find it useful in many circumstances to manipulate domestic political sentiments by masking private objectives with strong nationalist rhetoric. Whether such rhetoric was self-serving is usually not evident until after a war has begun or even until after it has ended. Moreover, even when non-rebels do stand to obtain benefits, such as territorial concessions, it is not clear that such benefits will outweigh the costs of genocidal violence inflicted on them by the dominant group.

How can the rebel leaders maintain support within the target group if they impose such costs on non-rebels? One answer is that non-rebel members of the target group might support rebel leaders if they believe there is a chance that

41. Indeed, much of the literature on the origin of civil wars suggests that elite rebel leaders are able to overcome collective action problems because they can obtain substantial spoils from fighting such as trafficking in contraband and looting. See Paul Collier \& Anne Hoefler, Greed and Grievance in Civil War (World Bank, Working Paper No. 2355, 2000) (finding evidence that greed is a better predictor of rebellion than grievance); see also Paul Collier, Rebellion as QuasiCriminal Activity, 44 J. CONFLICT REs. 839 (2000) (modeling loot-seeking rebellion).

42. For examples of the kinds of spoils available to rebel leaders in the wake of a peace settlement, see generally Bumba Mukherjee, Why Political Power-Sharing Agreements Lead to Enduring Peaceful Resolution of Some Civil Wars, But not Others, 50 INT'L STUD. Q. 479 (2006). For other examples that suggest that groups that pose the greatest threat to their adversaries get the lion's share of the benefits, see Robert A. Pape, The Strategic Logic of Suicide Terrorism, 97 AM. Pol. SCI. REv. 343 (2003) (noting that suicide terrorism has been on the increase because terrorists have learned that it pays).

43. See generally Collier \& Hoefler, supra note 41 (finding that the incidence of rebellion is not usually explained by a grievance motive, but by the atypical circumstances that generate profitable economic opportunities). 
the rebellion might yield substantial rewards for the target group. But if the rebellion progresses to a certain stage without such rewards from the dominant group, then it seems reasonable that at some point non-rebel members might conclude that the costs of the rebellion are likely to exceed the expected benefits.

Thus, a more plausible explanation for non-rebel acquiescence is that collective action problems will often make it difficult for non-rebels to hold rebel leaders accountable for their high-risk behavior. Indeed, the very logic that makes rebel leaders overcome collective action problems when they engage in provocative behavior against the dominant group-the presence of a substantial private good-will often make it difficult for non-rebels to organize against the rebel leaders. ${ }^{44}$ More importantly, non-rebels are often faced with a Hobbesian choice between incurring the wrath of rebel leaders for withholding support or otherwise facing the prospect of indiscriminate violence by the dominant group. ${ }^{45}$ Since rebel leaders are more likely than the dominant group to have better information about non-rebel members who do not support the rebel leaders, it might be more prudent for non-rebel members to support the rebel leaders in order to gain protection from the more indiscriminate violence perpetrated by the dominant group. ${ }^{46}$ As some commentators have observed, however, many non-rebels might very well choose not to support either side. ${ }^{47}$ This approach on the part of rebel leaders relies in part on the logic of strategic interaction. In the language of rational choice theory, one could say the rebel leaders anticipate the likely reactions of their more dominant adversaries based upon the available information about each other's resources, capabilities, and preferences. In conflict bargaining in a weak state where the dominant group in control of the government lacks both the capability and the resources to deploy targeted violence effectively, the rebel leaders are likely to gamble that the dominant group will resort to indiscriminate violence to achieve its objectives. In this picture, the weaker or poorer the state, the more likely it is to resort to

44. Collier, Rebellion as Quasi-Criminal Activity, supra note 41, at 839 ("One reason why economists are somewhat dismissive of grievance as a cause for rebellion is that the provision of justice . . . is a public good and so faces acute collective action problems. However, even when recruits are willing to fight for a cause rather than for their own self-interest, predation may be the sole means by which a rebellion can sustain itself financially.").

45. See T. David Mason \& Dale E. Krane, The Political Economy of Death Squads: Toward a Theory of State-Sanctioned Terror, 33 INT'L SruD. Q. 175, 175 (1989) ("[A]s the level of repressive violence escalates and becomes more indiscriminate, the option of remaining uninvolved is eventually precluded because nonelites can no longer assure themselves of immunity from political repression by simply remaining inert.").

46. See id. at 176 ("Under such conditions, [nonelites] can be induced to support rebel organizations by the promise of protection from indiscriminate violence by the state.").

47. See id. (" $[N]$ onelites caught in the crossfire between regime and rebels would prefer to remain uninvolved, devoting their efforts to the everyday tasks of securing subsistence."). Anecdotally, this observation is consistent with reported sentiments of certain Darfur residents who claim that the rebel leaders do not represent their interests. See infra text accompanying notes 102-07. 
indiscriminate violence to counter challenges to its authority. ${ }^{48}$ Stathis Kalyvas is rather explicit on this point:

[T] he persistent use of indiscriminate violence points to political actors who are fundamentally weak: this is the case with civil wars in failed states ... where high levels of violence emerge because no actor has the capacity to set up the sort of administrative structure required by selective violence. ${ }^{49}$

When a dominant group in a weak state is likely to resort to a second-best option of indiscriminate violence as a response to a rebellion, it gives the rebel leaders an opportunity to exploit the fallout of such violence in three ways. First, the rebel leaders will likely gamble that the resultant negative publicity from the suffering of their followers will propel domestic audiences in the Western world to lobby their politicians in favor of intervention. Second, because indiscriminate violence is by nature arbitrary and erratic, the rebel leaders can more easily escape punishment by the dominant group. ${ }^{50}$ Indeed, one of the ironies of indiscriminate violence is that because it targets the "innocent" and the "guilty" alike, it considerably reduces the costs of provocative behavior by the "guilty" rebel leaders. ${ }^{51}$ More specifically, because rebel leaders are more likely to have access to better information and resources about the dominant group's military strategy than their followers are, they can take measures that lower their risks of exposure to indiscriminate violence. If rebel leaders generally faced the same risks of reprisals as their followers, they might be less sanguine about adopting a provocation strategy against the dominant group in the first place.

Third, rebel leaders also tend to exploit the anger from dominant-group reprisals to rally dissenters and otherwise neutral non-rebels in the target group to their cause. In this picture, reprisals might drive non-rebels to seek protection from the rebel leaders, even when the rebel leaders do not otherwise enjoy significant political support among the target group. The rebel leaders also capitalize on the reprisals to isolate and marginalize politically moderate voices

48. For an analysis of the relationship between weak states and indiscriminate violence, see discussion infra Part Il.C. Other commentators have explained the prevalence of indiscriminate violence in weak states as rooted in the state's inability to engage in more accommodative strategies with the opposition. See, e.g., Mason \& Krane, supra note 45, at 184 . Indeed, the available empirical work suggests that states with weak institutions or poor states account for a significant majority of the outbreaks of civil wars. See Halvard Buhaug, Relative Capability and Rebel Objective in Civil War, 43 J. PEACE REs. 691, 695 (2006) ("[E]mpirical work has demonstrated that the frequency of domestic unrest is inversely related to state strength. Transitional and institutionally inconsistent regimes as well as impoverished countries account for a large majority of contemporary civil wars.").

49. Stathis N. Kalyvas, The Logic of Violent Civil War 171 (2006) (discussing examples across a wide range of conflicts).

50. See Mason \& Krane, supra note 45 , at 177 ("[M]ost of the victims of political violence are found among these nonelites, and their support and loyalty are what ultimately determine the outcome of the struggle between regime and opposition.").

51. See Kalyvas, supra note 49, at 154-55. 
within the target group, encourage recruitment, and raise funds for their violent operations. One observer points to such an effect of the Sudanese government's brutal tactics against civilians in Darfur: "To acquaint oneself with the rebels for even a few days is to discover the formula for an insurrection: kill a boy's kin, take a man's cattle, and a rebel is born." 52 In other words, the elevated sense of grievance from reprisals encourages more people to join the rebellion and helps rebel leaders keep their followers committed to a shared sense of ethnic identity or communal purpose in challenging the dominant group. ${ }^{53}$

\section{B. The Structural Factors That Lead to Bargaining Breakdowns}

Even if we concede that rebel leaders have a plausible reason to provoke a dominant group in the context of a high-risk rebellion, genocidal violence still seems inefficient. If humanitarian intervention merely increases the rebel groups' conflict bargaining leverage, why shouldn't both parties simply reach a settlement that reflects the expected outcome of such an intervention?

This Article suggests four reasons why bargaining breakdown is likely in the context of a suicidal rebellion that spurs genocidal violence. First, in the context of weak states where most incidents of genocidal violence take place, the authority of the regime is often susceptible to challenges from multiple groups. Thus, the dominant group might likely forego a bargaining outcome that might be efficient in the short run in order to send a strong signal of resolve to other potential rebels. Simply put, from the perspective of a dominant group that worries about developing a bad reputation with other potential rebel groups, the decision to go to war might not simply be a zero-sum game. ${ }^{54}$ So when the dominant group (or government) might also be confronting other potential challengers to its authority in the future, it has an incentive to refuse to settle despite the significant costs that might be associated with genocidal violence. The dominant group must factor in the effect of any conciliatory gestures toward a rebel group on the strategic calculus of other potential downstream rebels, especially when the upfront costs of initiating a rebellion are low. ${ }^{55}$ If the mere threat of violence by a rebel group could easily be used to

52. See Somini Sengupta, Sudan Government's Attacks Stoke Rebels' Fury, N.Y. TimEs, Sept. 11, 2004, at A1.

53. See Kalyvas, supra note 49, at 151-53 (2006) (discussing examples across a wide range of conflicts).

54. This insight draws on insights regarding the motivations of repeat litigants in the extensive law and economics literature. See Douglas G. Baird ET AL., Game THEORY AND THE Law 220 (1994) (observing that parties forgo beneficial trades to build credibility in future negotiations); Abhinay Muthoo, Bargaining Theory with Applications 327-31 (1999) (discussing the significant role of reputation on bargaining and illustrating with a simple bargaining model); Eric A. Posner, A Theory of Contract Law Under Conditions of Radical Judicial Error, 94 Nw. U. L. REv. 749, 765 (2000) (discussing the strategy of reputation-building among individual buyers and sellers).

55. In Africa, for instance, one commentator suggested that initiating a rebellion is often easier and less costly than opening up a new business. See Jeremy M. Weinstein, Africa's 
extract concessions from the dominant group, conciliatory gestures by the dominant group might actually increase the overall level of violence across future periods. Indeed, similar concerns have led some commentators to question the efficacy of negotiated settlements for long-term political stability, especially in the absence of a clear military victory by either side in the dispute. $^{56}$

Second, there is likely to be an asymmetry of information between the dominant group and the rebel leaders regarding which rebel leaders truly pose a threat to the dominant group. Ideally, in the context of a high-risk rebellion, the dominant group would prefer to make concessions only to dangerous rebel leaders. But because of the absence of any reliable information as to who constitutes a truly dangerous rebel leader, members of the rebel group will have an incentive to misrepresent their level of threat in order to attract bribes from the dominant group. In the standard rationalist account of war, bargaining breakdowns are most likely to occur when parties have important private information about their respective levels of commitment or resolve and have an incentive to misrepresent them. ${ }^{57}$ Thus, the dominant group must often rely on battlefield experience to obtain credible information as to the identity of truly dangerous rebel leaders. In such situations, it might be more rational for the dominant group to tolerate the costs of inflicting a certain amount of genocidal violence in order to avoid making inefficient concessions to both harmless and dangerous rebels.

Third, mutually beneficial bargaining might be hindered by the reality that some of the stakes in a suicidal rebellion might not be divisible. ${ }^{58}$ Often, rebel leaders might make demands both for targeted goods that benefit the rebel leaders exclusively as well as collective goods that benefit the larger target group as a whole. But some of the demanded collective goods, such as greater regional autonomy or territory, are not likely to be easily divided or monetized by the rebel leaders. If such goods have unique value to both sides in a dispute, the potential for bargaining breakdown increases significantly. ${ }^{59}$

Fourth, and most importantly, the prospect of humanitarian intervention is likely to amplify uncertainty about both the resolve of the combatants and the outcome of a conflict. In turn, such uncertainty increases the chance that both warring parties will suffer from information failure or have divergent expectations regarding the ultimate outcome of the rebellion.

Revolutionary Deficit, ForEIGN PoL'Y, July-Aug. 2007, at 70-71.

56. See Edward Luttwak, Give War a Chance, 18 Foreign AFF. 36 (1999).

57. See Fearon, Rationalist Explanations for War, supra note 37, at 390-93.

58. See Steven Shavell, Suit Versus Settlement When Parties Seek Nonmonetary Judgments, 22 J. LEG. STUD. 1 (1993) (modeling breakdown in negotiations when bargaining involves an indivisible item and nonmonetary relief).

59. See generally Monica Duffy Toft, The Geography of Ethnic Conflict: IDENTITY, INTEREST, AND THE INDIVISIBILITY OF TERRITORY (2003) (discussing the role that the indivisibility of land might pose to the resolution of ethnic conflicts). 
Two explanations are frequently offered for why rational disputants might fail to settle in the face of a mutually beneficial bargain: one being the "asymmetric information" model, the other the "divergent expectations" model ${ }^{60}$ In the divergent expectations framework, uncertainty arises because both parties make inconsistent forecasts about the prospects of victory. In the asymmetric information model, one party has private information about a crucial factor, such as combat readiness or resources, and has an incentive to misrepresent such information. These models have been used in both the legal literature on trials and the political science literature on warfare to explain how differing beliefs regarding each party's relative likelihood of success or the costs of prosecuting the conflict influence their decision to either settle a dispute or go to trial or war.

Although these two models sometimes yield different empirical predictions, ${ }^{61}$ both may be used to capture some of the basic intuitions about bargaining breakdown in the wake of an expected humanitarian intervention. The reason for tentatively embracing both models is that this Article does not aim to present an all-inclusive theory of bargaining breakdown during a civil war. Rather, its goal is to reassess how one particular event, humanitarian intervention, might contribute to bargaining breakdown according to the prevailing models that link combatants' uncertainty or inconsistent expectations to the onset of war. The observation that third parties can exacerbate bargaining dilemmas between combatants is not necessarily novel, although it has not been applied specifically to the humanitarian intervention context. As David Lake and Donald Rothchild have observed, with respect to the role played in civil conflicts by the assistance of ethnic allies from abroad, the involvement of such allies can exacerbate the strategic dilemma:

When groups overestimate the support they may receive from their ethnic kin, they may become intransigent and hold out for a better deal than the other group is willing to accept ... Likewise, if groups underestimate the support their opponents may receive ... they make 'too few' concessions to avert violence. ${ }^{62}$

The typical story of how war might result in the asymmetric information model is that leaders of one group might have information about their own military resources or resolve that their adversaries do not have. In such a

60. For a general discussion of these two approaches in the litigation context, see Joel Waldfogel, Reconciling Asymmetric Information and Divergent Expectations Theories of Litigation, 41 J. L. \& ECoN. 451, 453-57 (1998); see also Keith Hylton, Asymmetric Information and the Selection of Disputes for Litigation, 22 J. LEGAL STUD. 187 (1993). There is a similar divide in the literature attempting to explain why wars occur. Compare Fearon, supra note 37 (embracing an asymmetric information approach) with GEOFFREY BLAINEY, THE CaUSES OF WAR (1988) (adopting a divergent expectations approach).

61. See Walfogel, supra note 60 , at 452 .

62. See David A. Lake \& Donald Rothchild, Spreading Fear: The Genesis of Transnational Ethnic Conflict, in The International Spread of Ethnic Conflict 30 (David Lake \& Donald Rothchild eds., 1998). 
situation, if the adversaries believe such leaders have an incentive to misrepresent such information, then this dissembling behavior could create situations where both parties prefer fighting to a negotiated solution. ${ }^{63}$ The risk of humanitarian intervention could thus alter the strategic calculus in favor of going to war by increasing the importance of private information in the bargaining process.

Let us assume that the relevant risk of humanitarian intervention is "common knowledge" to both the dominant group and the rebel group with regard to the intervention: no party has greater access to information regarding the probability of humanitarian intervention than does the other. In the presence of such mutual uncertainty about the likelihood of intervention, neither party can predict with confidence the level of assistance that the rebels will receive. For instance, it might be unthinkable for the rebels to militarily engage a dominant group if both sides know that there is no chance that a third party will intervene in the ensuing conflict. But if both parties are unsure about the prospects of humanitarian intervention, then the risks of bargaining failure increase because neither side is likely to be fully aware of each other's scope of ignorance and both sides have an incentive to misrepresent their beliefs. But even if both parties were somewhat informed about the chances of intervention, the possibility of bargaining breakdown still remains if the rebels have private information about their level of resolve that they cannot communicate credibly to the dominant group. In other words, in the absence of common knowledge about rebel willingness to fight, the rebels cannot simply announce to the dominant group that the presence of humanitarian intervention has significantly increased their level of resolve, because the dominant group will have little reason to believe them. ${ }^{64}$

Turning to the divergent expectations model, the claim is that cases that do not settle will be concentrated among disputes close to the decision standard. ${ }^{65}$ In this framework, a trial is more likely when a tortfeasor's conduct was almost negligent or only slightly negligent, than when the tortfeasor was seriously negligent or completely careful. Why? Because disputants are more likely to make inconsistent judgments about the outcomes of disputes that are close to the decision standard. For instance, even a small error in the plaintiff's judgment will cause her to believe that she will win a significant judgment. ${ }^{66}$ Correspondingly, when the outcome of the dispute is close to the standard, a small error in the defendant's judgment will cause her to believe she will pay nothing. However, when the outcome of the dispute is far from the decision

63. See Fearon, Rationalist Explanations for War, supra note 37, at 395-96.

64. For more detailed analysis as to why combatants might have an incentive to misrepresent their level of resolve, see Fearon, supra note 37, at 395-401.

65. See George Priest \& Benjamin Klein, The Selection of Disputes for Litigation, $13 \mathrm{~J}$. LEGAL STUD. 1 (1984).

66. See id. 
standard (such as when the defendant is terribly negligent), it would take a much larger error in the disputant's judgment for the disputant to make a mistake over the dispute's likely outcome.

Similarly, in the context of a suicidal rebellion, the potential involvement of third parties is likely to alter the strategic calculus of the parties in a manner that could lead to a bargaining breakdown. This dynamic can be explained intuitively. For a rebel group to even have a hope of engaging in conflict bargaining with the dominant group, its threat of resorting to war has to be credible. In other words, the expected value of the spoils of war to the rebels, multiplied by the probability of the rebel group prevailing against the dominant group, has to exceed the expected costs to the rebels of prosecuting the conflict. But in the absence of any real prospect of third-party intervention, the "true" likelihood of rebel victory will often be slim. Such a scenario would require the rebels to make a greater error regarding the likely outcome of the war than would be necessary with a nontrivial possibility of third-party intervention. But if the rebel threat to wage war is not credible, the dominant group is not likely to entertain serious conflict bargaining with the rebels at all.

For a more concrete illustration: Let us imagine that a rebel group expects to obtain concrete benefits worth $\$ 1,000,000$ from wartime victory, and that each side is likely to incur fighting costs of $\$ 200,000$. Assume further that the rebel group's real probability of prevailing without the prospect of humanitarian intervention is 5 percent. In this case, for the rebels to believe that their threat to go to war is even credible, they would have to erroneously believe that their chance of prevailing is at least 20 percent, which is four times higher than their real chance. Otherwise, the expected value of going to war for the rebel group would actually be negative (i.e., 5 percent of $\$ 1,000,000$ minus $\$ 200,000$ ) and the dominant group would have no incentive to make a positive settlement offer to the rebels at all. Thus, the rebel group resembles the plaintiff in a tort dispute in which the defendant has exercised an exceedingly high level of care and the litigation costs are fairly high; in such circumstances, we would expect incompatible estimates of the outcome of the dispute between the combatants to be rare because it would require a fairly large error to push the rebels' beliefs over the true outcome threshold. ${ }^{67}$ In other words, given the objective lack of factors in favor of the rebels, the chances that both sides are likely to have divergent beliefs about what will happen on the battlefield should be small.

Let us change the facts slightly and assume that the prospect of third-party intervention increases the chance that the rebels will prevail against the dominant group to 25 percent. Let us further assume that the rebels erroneously believe that their chance of prevailing is 60 percent, while the dominant group

67. See Hylton, supra note 60, at 196 ("A central proposition of the Priest-Klein model of selection is that disputes in which the evidence points strongly toward either innocence or guilt are more likely to settle than those in which it does not."). 
erroneously believes that its chance of prevailing is close to 10 percent. Thus, the rebels will not settle for any amount less than $\$ 400,000$ (i.e., 60 percent of $\$ 1,000,000$ minus $\$ 200,000$ ) and the dominant group will not be willing to pay the rebels more than $\$ 300,000$ (i.e., 10 percent of $\$ 1,000,000$ plus $\$ 200,000$ ). There is no longer any prospect for agreement between the combatants and so they are likely to go to war. More importantly, however, bargaining breakdown occurs in this model even though neither of the combatants' errors was as far from the actual outcome as in the previous example.

To summarize, this model assumes that the disputants are more likely to have incompatible beliefs about the possible outcome of a dispute where the probability of liability is most uncertain-i.e., close to 50 percent. To the extent that the prospect of humanitarian intervention to protect rebels introduces a level of uncertainty about the outcome of a conflict that previously did not exist, it increases the chance of bargaining breakdowns between rebels and dominant groups that will lead to civil wars. Moreover, humanitarian intervention might actually make conflict bargaining against the dominant group a rational strategy for rebel groups, especially when without intervention the rebels' costs of going to war are likely to exceed the rebels' expected benefits.

\section{The Motivations of Perpetrators in High-Stakes Rebellions}

An integral piece of this perverse dynamic is the motivations of the perpetrators of the atrocities. Contrary to the received wisdom in the legal academy, ${ }^{68}$ evidence in the political science literature suggests that the leaders of dominant groups who engage in humanitarian atrocities are not necessarily motivated by irrational or fanatical hatred, but rather by a particular logic. These leaders usually perpetrate such atrocities to attain specific political objectives; $;^{69}$ in other words, where outright military victory might not be an available option against the rebel groups because of resource or political constraints, leaders of dominant groups will tend to use the threat of mass atrocities to coerce the rebel leaders to abandon their political demands. ${ }^{70}$ As

68. See Martha L. Minow, Between Vengeance and Forgiveness: Facing History After Genocide AND MAss Violence 50 (1998) (describing a perpetrator's behavior as irrational); Robert D. Sloane, The Expressive Capacity of International Punishment: The Limits of the National Law Analogy and the Potential of International Criminal Law, 43 STAN. J. INT'L L. 39,72 (2007) (suggesting that the same cost-benefit analysis we make in the domestic sense might not apply and that the perpetrators might not be rational).

69. Benjamin A. Valentino, Final Solutions: Mass Killing and Genocide in the Twentieth Century 69 (2004) ("My research . . . also suggests that perpetrators may view mass killing as a rational way to counter threats or implement certain types of ideologies."); Helen Fein, Patrons, Prevention and Punishment of Genocide: Observations on Bosnia and Rwanda, in THE Prevention of Genocide: Rwanda and Yugoslavia Reconsidered 5 (Helen Fein ed., 1994) ("Genocide is preventable because it is usually a rational act: that is, the perpetrators calculate the likelihood of success, given their values and objectives.").

70. See VALENTINO, supra note 69, at 69-70. 
such, the use of mass atrocities simply becomes another tool of coercion adopted by dominant groups, but it is more likely to be used by dominant groups in weak or insecure states that lack the military capabilities to force rebel leaders to sue for peace. ${ }^{71}$

Nonetheless, the behavior of perpetrators in high-stakes rebellions is still puzzling, especially when one considers that rebel leaders might be gambling on reprisals by such perpetrators in order to increase the chance of humanitarian interventions. Why would perpetrators allow themselves to be used as pawns by rebel leaders? More importantly, why would they not focus their efforts on killing or punishing rebel leaders, rather than targeting supposedly innocent and vulnerable members of the victim groups?

Although perpetrating atrocities might not necessarily be the optimal approach for quelling high-risk rebellions, it is not necessarily irrational. First, perpetrators might lack the resources or ability to engage in selective violence against armed rebel groups. For dominant groups in weak or failed states subduing and defeating the rebels by force of arms is not usually an option. ${ }^{72}$ In such circumstances, the state or the dominant group might likely resort to the blunt and arbitrary use of force against civilian populations as a non-ideal strategy to motivate the rebels to drop their political demands. As Jeffrey Herbst suggests in his study of African militaries, "Although these blunt strikes usually do not work, they should not be seen as irrational given the circumstances African leaders face. Leaders may feel they have no alternative than striking out blindly in order to stomp out insurgencies." ${ }^{, 73}$ Of course, there is no guarantee that this second-best approach will work, ${ }^{74}$ but such dominant groups usually operate in a realm of uncertainty where they cannot foresee the consequences of various policy alternatives.

Second, even when perpetrators are aware that leaders of rebel groups are strategically trying to provoke retaliation, they may still consider it rational to retaliate against such groups. In this picture, perpetrators from the dominant

71. See Mason \& Krane, supra note 45 , at $184-85$. Indeed, there is a growing literature that suggests that state weakness is a large factor in the onset of civil wars. See, e.g., James Fearon \& David Laitin, Ethnicity, Insurgency and Civil War, 97 AM. PoL. SCI. Rev. 75 (2003) (arguing that state weakness favors insurgency more than other factors such as ethnic and religious characteristics).

72. See Mason \& Krane, supra note 45, at 177 ("[E]scalating repression is perpetrated not because it has a high probability of success but because the weakness of the state precludes its resort to less violent alternatives."); see also KALYvas, supra note 49, at 171 (discussing the logic of indiscriminate violence among weak states).

73. See Jeffrey Herbst, African Militaries and Rebellion: The Political Economy of Threat and Combat Effectiveness, 41 J. PeAcE Res. 357, 362 (2004).

74. In the language of economics, these dominant groups in weak states are likely to resort to atrocities against rebel groups as a "second-best strategy" because the optimal strategy of defeating the rebels militarily through selective violence is either too costly or impractical. See R.G. Lipsey \& Kelvin Lancaster, The General Theory of Second Best, 24 REv. Econ. STud. 11 (1956). For a general application of the second-best theory to modern day constitutional theory, see Adrian Vermeule, Hume's Second-Best Constitutionalism, 70 U. CHI. L. Rev. 421 (2003). 
group are likely to rationally discount the probability that retaliation against the rebel groups will provoke a humanitarian intervention because such interventions are usually both politically and economically costly for the third parties involved. ${ }^{75}$ The perpetrators understand that even when the chance of humanitarian intervention is relatively remote, rebel leaders might still find it worthwhile to provoke the dominant group because the rebel leaders do not fully internalize the risks of their provocative behavior since non-rebel members of the target group bear the brunt of the violence.

To be sure, deploying selective violence against rebel leaders or indiscriminate violence against civilians does not exhaust the dominant group's options for responding to a rebellion. If there is a risk that the use of genocidal violence might eventually hurt the dominant group, why wouldn't the dominant group try instead to act in a conciliatory fashion toward the rebels by accommodating some of their key demands or by doing nothing? A fully developed response to this question is beyond the scope of this Article. While admittedly speculative, the analysis below suggests two possible explanations as to why dominant groups are unable or unwilling to ignore rebel provocations.

First, as mentioned earlier, a conciliatory strategy towards the rebels can be problematic from a long-run perspective, especially when the dominant group might be confronting other potential challengers to its authority in the future. Second, and more importantly, by failing to respond to rebel provocation, the leaders of the dominant group risk appearing weak and indecisive before a domestic audience, which might in turn spur demands for regime change or otherwise embolden the political opposition. At times, however, engaging in indiscriminate violence may seem to be the only costeffective method of checking the rebels available to the dominant group. And by pursuing such indiscriminate violence, the base from which the rebels draw their support may effectively be destroyed. But the use of indiscriminate violence may also inadvertently increase the chance of humanitarian intervention. While the latter outcome is admittedly undesirable for the dominant group, it may often be less costly than allowing the rebels' provocation to go unchecked and thereby increase the chance of involuntary regime change.

75. See Bruce Bueno De Mesquita \& George W. Downs, Intervention and Democracy, 60 INT'L ORG. 527, 630-32 (2006) (discussing the enormous political costs democratic leaders incur from interventions, especially when there is a risk that intervention will fail); Jack Goldsmith, The Self-Defeating International Criminal Court, 70 U. CHI. L. REv. 89, 93 (2003) ("Nations do not lightly expend national blood and treasure to stop human rights abusers in other nations."); David Luban, Intervention and Civilization: Some Unhappy Lessons of the Kosovo War, in GlobaL Justice and Transnational Politics: Essays on the Moral and Political Challenges of Globalization (Pablo de Greiff \& Ciaran Cronin eds., 2002) (observing that if the domestic audience subscribes to the belief that only wars in pursuit of national interest should be fought then avoiding any casualties in a humanitarian war becomes a priority for elected officials). 
To summarize, the dilemma imposed by humanitarian intervention is that, while it imposes a tax on the dominant group, it also often provides a subsidy to rebel leaders. This ambiguous incentive structure makes it rational for both rebels and the dominant group to act in ways that offer each a chance at achieving their first-best outcomes while guaranteeing to each at least their second-best outcomes. That is, by the rebel leaders provoking the dominant group to carry out genocidal violence; perversely, under such a scenario the main costs of such violence are borne by others-i.e., non-rebel members of the target group.

\section{III}

\section{CASE STUDIES FROM THE BALKANS AND AFRICA}

Two brief empirical cases from Darfur and Kosovo illustrate the logic of unintended consequences in the context of humanitarian interventions. ${ }^{76}$ In each case, the threat of humanitarian intervention influenced the calculus of both rebel leaders and perpetrators in complex and unpredictable ways. More specifically, the threat (or prospect) of humanitarian intervention seemed to have influenced rebel leaders to escalate provocative behavior against a dominant group, even when the provocation would likely result in genocidal violence against civilian members of the rebel leaders' group.

Rebel confidence in a provocation strategy was bolstered in part because they had recently witnessed other groups who had successfully used violence to instigate humanitarian intervention or external pressure against the dominant group. The decisions to engage in high-stakes rebellions in both of these cases also significantly increased the political stature of marginal rebel leaders and spoilers who previously had little or no political capital or leverage among the host communities they purported to represent. Finally, rebel leaders in both cases seemed to consider provocation a worthwhile strategy even if the chances of a humanitarian intervention were slim because they personally bore very few direct risks from any reprisals from the dominant group. The rebel leaders tended to view even low prospects of humanitarian intervention optimistically because they rarely internalized the full costs of their provocative behavior.

Of course, these two cases are not sufficient to demonstrate that humanitarian interventions will invariably escalate atrocities. Instead, they illustrate that the relationship between humanitarian intervention and atrocities is sufficiently ambiguous to warrant closer examination by policy makers and legal academics.

76. Other commentators have suggested a similar unintended dynamic in the Bosnian and Rwandan civil wars. See, e.g., Alan J. Kuperman, Provoking Genocide: A Revisited History of the Rwandan Patriotic Front, 6 J. GEN. Res. 61 (2004) (Rwanda); Kuperman, in Gambling on Humanitarian INTERvention, supra note 32, at 1 (regarding Bosnia and Kosovo). 


\section{A. DARFUR}

At first glance, the Darfur crisis in Sudan seems like a puzzling case to illustrate the pitfalls of humanitarian intervention. After all, much of the commentary on the crisis assumes that it has been largely ignored by the international community; ${ }^{77}$ indeed, foreign observers and nongovernmental organizations tend to blame the reluctance of Western powers to intervene for the escalation of the crisis. ${ }^{78}$ In reality, the opposite is true: Darfur's crisis has been partly exacerbated by the level of outside attention it has received over the past four years. While much of that attention has been well intended and has helped publicize the Darfuris' plight, it might have unintentionally compounded the crisis by fueling intransigence and high-risk provocative behavior on the part of Darfur rebel leaders.

A stark illustration of the perverse role of outside intervention in the Darfur crisis comes from the multiple efforts by the United Nations and the African Union to negotiate ceasefires to the conflict. In a series of peace talks culminating in Abuja, Nigeria, in 2006, all but one of the rebel groups categorically rejected a peace plan proposed by outside mediators, including African Union leaders and then-U.S. Deputy Secretary of State Robert Zoellick. $^{79}$ Surprisingly, the Sudanese government agreed to the plan, even though it was presented by the mediators on a "take it or leave it" basis in order to force the government's hand. ${ }^{80}$ The plan would have required that the government disarm all government militias in the region and devote millions of dollars in aid to reconstructing Darfur and compensating victims of the humanitarian crisis. Nonetheless, two main rebel groups, the Abdel Wahid faction of the Sudanese Liberation Army (SLA) and the Justice and Equality Movement (JEM), refused to sign the agreement. The Abuja scenario repeated itself again in 2007 when the Libyan government hosted another round of peace talks and invited all rebel groups, including minor splinter rebel groups, to participate. ${ }^{81}$ Once again, the Sudanese government suggested its willingness to

77. See Harold Koh, Restoring America's Human Rights Reputation, 40 CORNELL INT'L L.J. 635, 653 (2007) ("The crisis in Darfur remains an international disgrace. The United States sadly has failed to lead the way in preventing what Secretary of State Colin Powell forthrightly called a 'genocide' several years ago. 'Never again' should not mean 'Never again, except in Africa."'); Romeo A. Dallaire, Looking at Darfur, Seeing Rwanda, N.Y. TimES, Oct. 4, 2004, at A25.

78. See Human Rights Watch, Too Little, Too Late: Sudanese and International RESPONSE (2004), available at http://hrw.org/reports/2004/sudan0504/8.htm\# Toc71531709.

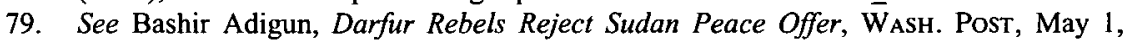
2006, at Al; see also Alex de Waal, Darfur: The Inside Story, New AfricAN, April 2007, at 29 [hereinafter Inside Story].

80. For an in-depth discussion of the negotiations, see Darfur's Fragile Peace Agreement, AFr. BRIEFING No. 39 (Int'l Crisis Group, Brussels, Belg.), June 20, 2006, at 2.

81. See Jeffrey Gettleman, Rebel Unity is Scarce at the Darfur Talks in Libya, N.Y. Times, Oct. 31, 2007, at Al [hereinafter Rebel Unity]. 
negotiate, ${ }^{82}$ but many of the key rebel groups did not even bother to show up to the talks. ${ }^{83}$

But why would the Darfur rebel groups refuse to compromise with the Sudanese government even though doing so would likely avert further atrocities? The simple answer is that they believed they could profit from holding out. Even though these rebel groups had almost no chance of prevailing militarily against the Sudanese government, they believed that outside humanitarian intervention would eventually tip the balance of conflict bargaining in their favor. Therefore, they refused to back away from the most strident aspects of their negotiating positions even when those demands were "unrealistic." 84 As intimated by Abdel Wahid, the leader of one of the main rebel factions that refused to sign the Abuja accord, verbal assurances of implementation of the agreement from the U.S. government were not sufficient: "I need a guarantee for implementation like in Bosnia."85

A 2005 report by the International Crisis Group (ICG) supports the notion that outside support loomed large as part of the rebels' strategy: "The rebels have equated [international] condemnation of Khartoum as support for their cause, and this has hardened their negotiating positions. ${ }^{, 86}$ Even Alex De Waal, an adviser to the African Union mediation team who is not known to be well disposed to the Sudanese government, has conceded that rebel leaders like Abdel Wahid were hesitating to cooperate in negotiations because they were "banking on outside military intervention that would drive the Sudanese army from Darfur.",87

The Darfur rebel leaders were gambling on a greater role by Western nations because they were firsthand witnesses to a recent episode where it seemed to work: they had observed closely how overt pressure from the United States had led the Sudanese government to make generous concessions as part of the 2004 agreement to end the four-decade-old civil war between the Sudanese government and the Sudan People's Liberation Army (SPLA) of southern Sudan. ${ }^{88}$ Even though the SPLA had failed to make significant military headway against the Sudanese government, the international community managed to extract generous commitments from the government,

82. See Jeffrey Gettleman, Sudan Declares Cease-Fire at Darfur Peace Talks, N.Y. Times, Oct. 28, 2007, at A3.

83. See Gettleman, Rebel Unity, supra note 81.

84. Darfur: The Failure to Protect, Afr. Rep. No. 89 (Int'l Crisis Group, Brussels, Belg.), Mar. 8, 2005, at 14 [hereinafter Darfur: The Failure to Protect]. As Alex de Waal has suggested elsewhere, the real underlying goals of the two hold-out rebel groups was regime change in Khartoum but the international support for that objective was pretty weak. See Alex de Waal, Briefing: Darfur, Sudan: Prospects for Peace, 104 AFr. Afr. 127, 131-32 (2005).

85. de Waal, Inside Story, supra note 79, at 30.

86. See Darfur: The Failure to Protect, supra note 84, at 9.

87. Alex de Waal, The Wars of Sudan, Nation, Mar. 19, 2007, at 18.

88. See id. at 16-18 (discussing the background of the North-South war and the eventual peace settlement ending the conflict). 
including an agreement to set up a separate vice president for the south, an oil resource sharing arrangement, and an agreement to hold a referendum on southern secession in 2011. ${ }^{89}$

Indeed, many of the demands made by the Darfur rebels, such as the demand for a separate vice presidency for the region, ${ }^{90}$ mirror some of the concessions made by the Sudanese government to the SPLA. The negotiations that led to the 2004 North-South agreement, which specifically excluded any governmental commitments on Darfur, gave the Darfur rebels reason to believe that they too could benefit from Western intervention (or attention) if they too mounted an offensive rebellion against the Sudanese government, despite the unfavorable military odds they faced. ${ }^{91}$ In any event, as many experts on the region have observed, the North-South conflict and the Darfur rebellion are inextricably linked. ${ }^{92}$ Indeed, the Darfur rebels had unsuccessfully attempted to make their demands a part of the original North-South negotiation; it was only upon being ignored that they resorted to force of arms. ${ }^{93}$

At bottom, until the Darfur rebels first launched their insurrection against the Sudanese government in two raids in February and April of 2003, there was virtually no genocidal violence in the region. ${ }^{94}$ The second raid, which consisted of a surprise attack on an airport in El-Fasher, was surprisingly ambitious and brazen: the rebels immediately killed thirty government soldiers, captured the air base commander, and seized several military aircraft. ${ }^{95}$ According to U.S. government sources, they also summarily executed approximately two hundred government soldiers they had captured as prisoners of war. ${ }^{96}$ To be sure, the Darfur rebels had legitimate grievances against the Sudanese government, which included long-standing government neglect of the region as well as ethnic marginalization by the Arab leadership in Khartoum. ${ }^{97}$

89. See id.

90. See Adigun, supra note 79.

91. See Darfur Rising: Sudan's New Crisis, Afr. ReP. No. 76 (Int'l Crisis Group, Brussels, Belg.), Mar. 25, 2004, at i [hereinafter Darfur Rising] ("Rebels . . not participants in the IGAD peace talks, concluded that they had to fight lest decisions on power and wealth sharing for the entire country be taken without them"); Patrick Johnston, Negotiated Settlements and Government Strategy in Civil War: Evidence from Darfur, 9 Civ. WARS 359, 364 (2007) ("[T]he Sudanese go' ernment's agreement to make significant concessions to the Sudan People's Liberation Army (SPLA) in southern Sudan ... gave Darfur home defense militias reason to believe that civil war . .. would yield significant political gains.").

92. See Samantha Power, Dying in Darfur, Can the Ethnic Cleansing in the Sudan be Stopped, New YoRKER, Aug. 30, 2004, at 60-62 (observing that Darfuris decided that to achieve their goals, they would have to replicate what John Garang, the SPLA leader, had done in the South). Indeed, Garang apparently also provided counsel to the Darfur rebel leaders about how to successfully organize an insurrection. See Julie Flint \& Alex de WaAl, Darfur: A Short HISTORY OF A LONG WAR 81-82 (2005).

93. See Darfur Rising, supra note 91 , at i; Johnston, supra note 91 , at 365 .

94. Gerard Prunier, Darfur: The Ambiguous Genocide 92, 95-96 (2007).

95. See id. at $95-96$.

96. See id.

97. See id. at 81-91 (detailing grievances by the Darfur groups against the central 
But until the negotiations that ended the North-South war, the Darfur leaders did not resort to rebellion as a tactic to address their grievances, and the government rarely utilized strong-arm tactics in response. ${ }^{98}$ Occasional fighting did break out between ethnic African and nomadic Arabs over grazing rights in the Darfur region, but most of these conflicts were contained and occurred sporadically during the 1980s. Prior to 2003, both the Arabs and the ethnic Africans in the region had managed to address their differences without resorting to large-scale violence. ${ }^{99}$

Thus, the event that triggered the 2003 insurrection and the subsequent backlash by the Sudanese government was the North-South peace negotiations. Other competing theories as to why the Darfur rebels launched their rebellion fall short. For instance, articulated grievances about ethnic marginalization were longstanding but were hardly increasing; indeed, from the early independence period until the unexpected airport ambush by rebels in 2003, the Sudanese government approach to the Darfur region was one of benign neglect. At the time the North-South peace agreement was being negotiated, none of the participants in the talks, including the outside mediators, thought the problems in the Darfur region were significant enough to be addressed as part of the agreement. $^{100}$

Eventually the Darfur rebel leaders' strategy did attract significant outside attention, especially by the Western media and governments, but not quite the military intervention that they hoped. However, it is premature to suggest that the rebel leaders' approach was a strategic failure. Commentators like Alex De Waal are correct to suggest that rebel leaders like Abdel Wahid are misguided because none of the major powers are ever likely to have the appetite for the kind of large-scale military intervention they are expecting. ${ }^{101}$ Instead, the rebels' tactics have largely alienated many of the Western powers they are seeking to court. As one State Department official put it:

The first notion anyone's got to disabuse themselves of . . is that there are any good guys in this. There aren't. The S.L.A. started this war,

government).

98. Johnston, supra note 91 , at 364 ("Although violent dispute had arisen sporadically since the 1970s, Arabs and non-Arabs lived for decades in the same region without large-scale organized warfare .... Despite the emergence of a security dilemma, civil war still did not occur.").

99. See id.

100. As some commentators have suggested, both the Sudanese government and the Western mediators in the North-South conflict ignored the Darfuris' request to be included as part of the North-South agreement because the perception was that the events in Darfur were somewhat minor and secondary. See Scott Anderson, How Did Darfur Happen?, N.Y. Times, Oct. $17,2004, \S 6$ (Magazine), at 55-56 ("Somewhat impertinently, the S.L.A. also demanded to be included in the north-south peace talks being brokered by the Americans and just then reaching fruition. Not surprisingly, given its track record of ignoring Darfur, the Khartoum regime paid these latest malcontents little attention.").

101. See de Waal, Inside Story, supra note 79, at 30. 
and now they and the Justice and Equality Movement are doing everything possible to keep it going .... [T] hey've been very content to sit back, let the village burnings go on, let the killing go on, because the more international pressure that's brought to bear on Khartoum, the stronger their position grows. ${ }^{102}$

Ironically, however, while the Darfur rebel leaders are not likely to achieve their preferred objective of Western military intervention, they have nonetheless improved their status as political actors. When measured against the pre-rebellion baseline, the rebel leaders are better poised to obtain political spoils that would have been unlikely absent the current international attention the crisis is receiving.

The rebel leaders have already benefited significantly on one front. The international focus on the Darfur crisis has helped catapult many of the rebel leaders into important regional political brokers, even though it is not clear that their rebel activities were supported by the populations they purport to represent. Indeed, the government has already offered targeted benefits, including high political positions and cars, to certain rebel leaders to encourage them to lay down their arms. ${ }^{103}$ But as one commentator observed from field research conducted a year after the war started: "[M]ost of the Darfur people interviewed for this research ... - and most of them supportive of the rebels agenda for change-stated both their opposition to armed rebellion, and their belief that the current violence escalated in response to the insurgency." 104 Certain rebel leaders who have profited from the crisis do not even purport to represent any of the significantly large ethnic groups in the Darfur region. ${ }^{105}$ More importantly, during a recent visit to Darfur by U.S. officials involved in mediating the conflict, various nongovernmental organizations and community groups in the region publicly expressed concerns that these rebel leaders do not act in their interests. ${ }^{106}$ Because of such concerns about the lack of agency given to ordinary Darfuris, the United Nations has attempted to organize representative councils that will better articulate the interests and concerns of ordinary Darfuris during peace negotiations. ${ }^{107}$ The rebel leaders have not welcomed this development. As Andrew Natsios, the U.S. Special Envoy to the

102. Anderson, supra note 100 , at 62 .

103. See Johnston, supra note 91 , at 372 .

104. See Victor Tanner, Sudan Advocacy Coalition, Rule of Lawlessness: Roots AND REPERCUSSIONS OF THE DARFUR CRISIS 17 (2005), available at www.sudanarchive.net/cgibin/sudan? $\mathrm{a}=$ pdf\&d=Dunepd257.1\&dl=1.

105. See Johnston, supra note 91, at 365 ("Ethnic Zhagawa, including Minni Minawi . . quickly gained increased power within the SLA despite comprising only about eight percent of Darfur's population.”).

106. Andrew Natsios, the former U.S. Special Envoy to Sudan, said that during a visit to Darfur in 2007, NGOs and women's groups informed him that the "rebels were make increasingly extreme demands at the negotiating table, which would only prolong the war." Andrew S. Natsios, Why I Think We Can Still Save Darfur, WASH. Post, Feb. 4, 2008, at B3.

107. See id. 
Sudan was informed during a recent visit to the region: "[O]ne of the rebel leaders, Abdel Wahid-al-Nur ... has threatened through his henchmen in the camps to kill anyone who volunteers to serve on the councils."108

Far from constituting a cohesive political front, the rebel leaders consist largely of unelected spoilers from different ethnic groups in the Darfur region and beyond, who have disparate interests, and who are often at odds with each other. For instance, in July 2005, Mini Minawi's Zaghawa faction of the SLA launched an attack against the Abdel Wahid's Fur faction, killing more than seventy people and raping thirty-nine women. ${ }^{109}$ Since the 2003 rebellion itself, the rebels have further splintered into dozens of groups, each with a different agenda, and all in competition with each other for the political spoils that are likely to emerge from any eventual settlement. ${ }^{110}$ Some of the rebel leaders and their key supporters come from backgrounds that are altogether divorced from Darfur: for example, Hassan al-Turabi, who is a sponsor of the JEM, is of Arab origin and was formerly spiritual mentor to both President El-Bashir and Osama Bin Laden; ${ }^{11}$ and Abdel Karim Bari (Tek) of the National Movement for Reform and Development, is a former Zaghawa dissident officer in the Chadian Army who is currently on the United Nations sanctions list for allegedly committing war crimes. ${ }^{112}$

While provocation has yielded the Darfur rebel leaders some concrete political benefits, it has rarely come with any significant costs to themmilitarily or otherwise. Since the rebellion started five years ago, very few key rebel leaders have been killed or seriously injured in battle. For the most part, the rebel leaders have managed to successfully insulate themselves directly from the fallout of much of the carnage occurring in Darfur. Indeed, one of the key rebel leaders, Abdel Wahid, has safely ensconced himself in Paris for the past two years, yet he continues to make trips to internationally-mediated peace negotiations. Of course, some rebel leaders have suffered from the Khartoum government's ability to strip away a portion of their political leverage through its "divide and rule" tactics, but very few of them are worse off than they were at the beginning of the rebellion. ${ }^{113}$

In response to the rebels' provocative behavior, the Sudanese government has adopted an unconventional strategy: deploying nomadic Arab militias

108. Id.

109. See Johnston, supra note 91 , at 368 .

110. See id. at 366-72 (discussing the splintering of the Darfur rebel groups).

111. See Prunier, supra note 94, at 81-88 (discussing the ebbs and flows of Turabi's career in Sudanese politics); see also David Blair, Man Who Harboured Bin Laden Is Lodestar for Terrorists, DaILy TelegraPH (London), Jan. 30, 2006, at 17.

112. See Who Are Sudan's Darfur Rebels?, BBC News, Feb. 24, 2009, http://news.bbc.co.uk/2/hi/africa/7039360.stm.

113. See Johnston, supra note 91 , at 372 (observing that even rebel leaders who have committed egregious war offenses have benefited generously from Khartoum's bounty). 
known as the Janjaweed to attack and raze black Darfur settlements. ${ }^{114}$ The Sudanese air force has also engaged in air raids in support of the militias, ${ }^{115}$ but the Sudanese government's decision to engage the rebels through nonconventional military means has been the source of significant controversy within the ruling regime. ${ }^{116}$ In any event, the Janjaweed's brutal tactics have deservedly proven to be an international public relations debacle for the Sudanese government. But from a purely military standpoint, it is not clear that the Sudanese government's decision to deploy the Janjaweed was irrational.

The Sudanese government had to confront two unpleasant realities about a conventional military approach at the early stages of the rebellion. First, because the regular Sudanese Army had a significant number of black Darfur conscripts, its loyalty in quashing the rebellion in the region was suspect. ${ }^{117}$ Second, the use of nonregular Arab militias was considered much more cost effective than deploying conventional forces. ${ }^{118}$ This latter factor led one commentator to declare that the Sudanese government was waging a "counterinsurgency on the cheap." of African militaries in quelling rebellions, ${ }^{120}$ including that of the Sudanese army in fighting the southern SPLA rebels, the Sudanese government might have rationally conjectured that a blunt strike against civilian targets by hired militias would be its most effective option. Perhaps the logic of Khartoum's approach is rooted in the belief that it needed to clamp down as forcefully and cheaply as possible against the Darfur rebels to ward off any future rebellions, especially in a context where the regime was viewed as vulnerable and weak. ${ }^{121}$

In hindsight, the Sudanese government's strategy backfired. The Janjaweed unleashed a savage counterinsurgency that has left thousands of innocent civilians dead and millions displaced and has evoked an international outcry that has had the unintended effect of elevating the stature of several of the rebel leaders.

While the Sudanese government might have lost the public relations battle against the rebels, its unconventional tactics may have yielded some concrete

114. FLINT \& DE WAAL, supra note 92, 101-06.

115. See id. at 106-11.

116. For details of the internal regime dispute over the use of the Janjaweed, including the vehement opposition of General Suleiman, the governor of North Darfur, see FLINT \& DE WAAL, supra note 92, at 97-102.

117. See PRUNIER, supra note 94, at 97.

118. See id. at $97-100$.

119. See Alex de Waal, Counter-Insurgency on the Cheap, London REv. Books, Aug. 5, 2004, available at http://www.lrb,co.uk/v26/n15/waal01_html.

120. See Herbst, supra note 73, at 362 .

121. This logic makes sense in the African context, where rebellions are relatively cheap to initiate. See Weinstein, supra note 55, at 71 ("In much of Africa, the barriers to entry for rebel movements are too low. With states often incapable of projecting power outside of cities and insurgents easily able to finance their own private armies, just about anyone can hoist a flag, arm recruits, and launch a revolution."). 
military benefits. More specifically, its strategy of alternately attacking civilian settlements and then offering generous concessions to particular rebel spoilers has splintered the rebel groups significantly, thereby weakening the rebels' negotiating leverage. ${ }^{122}$ This strategy has potentially significant downstream benefits for the government because it suggests that even if a comprehensive peace settlement is eventually negotiated, the government may be able to easily subvert the implementation of the agreement on account of the lack of rebel unity. The latter scenario is not entirely hypothetical. Indeed, the southern SPLA has repeatedly threatened to drop out of the current coalition government because it alleges that the Khartoum government has consistently undermined the implementation of the 2004 North-South agreement. ${ }^{123}$

Let us assume for the moment that a negotiated settlement is somehow possible in Darfur. How stable is it likely to be? Given Khartoum's track record in implementing the North-South agreement, it has shown that it is adept at scuttling long-term power-sharing commitments and playing off various opposition groups against each other. ${ }^{124}$ Since the Darfur rebel groups are far less cohesive and organized than the SPLA, the prospects for any sustainable peace agreement do not look particularly promising.

Moreover, given the reluctance of Western governments and the African Union to launch a more robust intervention force now that Darfur is prominently in the media spotlight, it is unlikely that the international community will be willing to invest the resources to monitor the long-term implementation of an agreement once the "CNN effect" surrounding the crisis has receded. But whatever the outcome of any future peace negotiations between the Sudanese government and the rebels, it is likely to include tangible benefits to the rebel leaders, such as government posts, money, or other perks. Indeed, various rebel spoilers have already taken advantage of the government's generosity in return for a commitment to undermine other rebel leaders who are still holding out. ${ }^{125}$ The Sudanese government might also succeed in politically emasculating the Darfur region if it displaces or kills a significant portion of its residents. Thus, regardless of how the Darfur crisis unfolds, the upshot for both the rebel leaders and the Khartoum regime is that they can potentially improve their position relative to their status quo ex ante. In the end, the groups that stand to lose are the long-suffering residents of Darfur.

122. See Johnston, supra note 91, at 366-71 (discussing how the government's strategy of making concessions to rebel spoilers has significantly splintered the Darfur rebels).

123. See Sudan's Comprehensive Peace Agreement: Beyond the Crisis, Afr. Briefing No. 50 (Int'l Crisis Group, Brussels, Belg.), Mar. 13, 2008 [hereinafter Sudan's Comprehensive Peace Agreement].

124. See id.

125. See Johnston, supra note 91 , at 372 (discussing benefits that Darfur rebel spoilers have already received from the government, including cars and government posts). 


\section{B. Kosovo}

The events that compelled the Kosovo Liberation Army (KLA) to launch a rebellion against the Serbian government have been the source of an engaging and lively academic debate about the merits of the North Atlantic Treaty Organization's (NATO) Balkan strategy. ${ }^{126}$ The conventional narrative, at least in NATO policy circles, was that it was extremist Serbian elements in Belgrade who fostered the conditions that created both the KLA and the subsequent humanitarian crisis that the rebellion spawned in 1999. ${ }^{127}$ According to that narrative, Slobodan Milošević instigated the crisis in 1989 by revoking Kosovo's regional autonomy and embarking on a systematic campaign to marginalize the Albanian majority in the region. ${ }^{128}$ The KLA was purportedly created as a response to Serbia's discriminatory policies. In 1998, after facing degrading treatment by the Serbs for a decade, the Kosovar Albanians were left with no option but to launch a rebellion. NATO then had to intervene in 1999 to avert Serbian genocidal violence against Kosovo's Albanian majority.

Recently, commentators have begun to question this narrative. Alan Kuperman has persuasively argued that it was the threat of NATO intervention that created the dynamic that led to Serbia's genocidal violence against the Kosovar Albanians in the first place. ${ }^{129}$ More specifically, Kuperman shows that the KLA initiated a high-risk rebellion in 1998, hoping that the prospect of a brutal Serbian response would tip NATO's decision calculus toward military intervention. ${ }^{130}$ Provoking a genocidal response from Belgrade seemed to be a worthwhile and rational gamble by the KLA because the KLA had recently witnessed how similar genocidal violence by the Serbs had instigated humanitarian intervention by NATO on behalf of Muslim rebels in Bosnia. ${ }^{131}$ The KLA rebel leaders understood that a military victory against the more dominant Serbian army was implausible, yet the prospect of a NATO intervention dramatically lowered the risks of a provocative rebellion. As one of the Kosovar Albanian negotiators subsequently conceded in an interview: "The more civilians were killed, the chances of intervention became bigger, and the KLA of course realized that." $" 132$

126. See, e.g., Ted G. Carpenter, NATO's Empty Victory: A Postmortem on the BALKAN WAR (2000) (collection of essays debating NATO's Kosovo strategy) [hereinafter Nato's Empty Victory]; Ivo H. Daalder \& Michael E. O'Hanlon, Winning Ugly: NATO's WAR To SAvE Kosovo (2000) (discussing whether the war could have been avoided).

127. See Statement by Secretary of State Madeleine K. Albright, Situation in Kosovo, Oct. 8, 1998, in Marc Weller, The Crisis in Kosovo 1998-1999, 1 International Documents and Analysis 378 (1999); see also James George Jatras, NATO's Myths and Bogus Justifications for Intervention, in NATO's EMPTY VICTORY, supra note 126, at 21-22.

128. See Jatras, supra note 127 , at 21 .

129. See Kuperman, in Gambling on Humanitarian InTERvention, supra note 32, at $10-12$.

130. See id.

131. See id.

132. Id. at 12 (quotations omitted). 
This Article's argument complements this growing critique by showing that the rebellion and the subsequent NATO intervention transformed the KLA leadership from relative obscurity into key power brokers. More specifically, the KLA exploited the post-rebellion Serbian reprisals to shore up its marginal status as a political organization and consolidate allegiance to its goals and tactics, even when it barely enjoyed any significant support among Kosovar Albanians. Also, instead of dampening the prospects of atrocities, the threat of a NATO intervention emboldened the resolve of hard-line KLA leaders, who took advantage of the threat to isolate and weaken moderate Kosovo leaders who preferred a more conciliatory approach to resolving the crisis. In sum, the KLA employed appeals to ethnic solidarity and nationalist sentiments to alter the domestic political landscape in Kosovo in favor of violently seeking independence.

Prior to 1997, the KLA was a relatively marginal player in Kosovo's political scene. As an ideological group committed to violent political challenge, the KLA faced daunting challenges in its quest to attract both resources and recruits. As Tim Judah observed: "The KLA [in 1996] consisted of some 150 men and ... most Kosovars, let alone people outside of Kosovo, had heard of them." 133 Despite some Albanian disenchantment with Belgrade's decision to strip Kosovo of its autonomy in 1989, Kosovar Albanians under the leadership of Ibrahim Rugova for the most part embraced a pragmatic approach to resolving the crisis. ${ }^{134}$ Rugova favored passive resistance and hoped informal international pressure would bring Belgrade to the table to negotiate the autonomy issue. ${ }^{135}$ Although there were some simmering grievances, very few Kosovar Albanians seemed to have the appetite to embark on what seemed like a hopeless rebellion against the Serbs. More importantly, the Serbian leadership felt little need to adopt strong-arm tactics against the Kosovar Albanians; thus, until the KLA started escalating attacks against Serbian targets in 1997, there was hardly any large-scale violence deployed by either side in the region.

Two events foreshadowed a change in the Kosovo political landscape that significantly diminished the political stature of moderates like Rugova and emboldened the KLA. The first was the Dayton Peace Accords of 1995, under which NATO forced the Serbian leadership to make significant concessions to both Bosnian Muslims and the Croatians. ${ }^{136}$ The second was the Albanian pyramid financial scandal of 1997, which triggered a descent into political anarchy in Albania; the subsequent looting provided a ready source of both guns and funds to the KLA rebels. ${ }^{137}$ The Dayton Accords suggested to a growing number of Kosovar Albanians that a violent insurrection against the

133. Tim Judah, Kosovo: War and Revenge 134 (2d ed. 2002).

134. See id. at 98-111.

135. See DaAlder \& O'HANLon, supra note 126 , at 8-9.

136. See JUDAH, supra note 133, at 120.

137. See id. 
Serbs might be a plausible strategy for gaining concessions from the Serbian government. In other words, after both the Bosnians and Croatians had launched violent rebellions against the Serbians despite overwhelming military odds, the West intervened in response to the genocidal retaliation and facilitated a peace settlement that forced the Serbians to make significant concessions. To the mediators in Dayton, however, Kosovo was not a key priority and it was not discussed as part of the settlement. ${ }^{138}$ For Kosovar Albanians who chose a more peaceful and conciliatory approach to the Serbs, the Dayton Peace Accords seemed like a slap in the face. ${ }^{139}$

The KLA resorted to a two-prong strategy to capitalize on the fallout from Dayton. First, they escalated their attacks against Serbian targets and launched a full-blown rebellion in 1998 hoping to trigger reprisals. The KLA then used the Serbian crackdowns to try to convince previously skeptical Kosovar Albanians that violent resistance was the only available option. The KLA leaders calculated, somewhat correctly, that ordinary Kosovar Albanians would be more sympathetic to a hard-line nationalist stance against the Serbs, given the concessions made by the Serbs to the Bosnian Muslims and Croats in Dayton. ${ }^{140}$ Second, the KLA gambled that the worsening humanitarian crisis in the region would make it difficult for NATO to ignore Kosovo as it did in Dayton. Ironically, despite the fact that the KLA was able to recruit a large number of participants and grew substantially in its first years of operation, it still did not enjoy significant political support among ordinary Kosovar Albanians. In an election held in March 1998, the year the KLA launched its rebellion, Rugova and his moderate Democratic League of Kosova (LDK) party gained an overwhelming victory despite KLA calls to boycott the election. ${ }^{141}$

In the end, the escalation of the crisis in Kosovo did get NATO's attention. After a series of botched attempts at peaceful negotiations, NATO issued an ultimatum to Milošević in 1999 at Rambouillet, France to surrender Kosovo's sovereignty for an interim period of three years or risk a sustained bombing attack. ${ }^{142}$ Milošević refused to accede to NATO's demands, and shortly thereafter NATO mounted an aerial bombing campaign against Serbia. ${ }^{143}$ Apparently, NATO strategists assumed that either Milošević would cave quickly after the bombing started or that the bombing itself would trigger some kind of regime change in Serbia. ${ }^{144}$ In the end, NATO's strategy backfired. Rather than forcing Milošević to back down immediately, it caused

138. See DAALDER \& O'HANLON, supra note 126 , at 9.

139. See JUDAH, supra note 133, at 124-26.

140. See Miranda Vickers, Between Serb and Albanian: A History of Kosovo 289 (1998).

141. See ЈUDAH, supra note 133, at 146.

142. See id. at 206-26.

143. See id. at 229-34.

144. See id. at 228-29. 
him to escalate the atrocities against the Kosovar Albanians. By the time Milošević capitulated, after eleven weeks of NATO bombings, Serbian forces had killed as many as five thousand Kosovar Albanians and displaced or deported another eight hundred and fifty thousand. ${ }^{145}$

The Kosovo crisis reveals the kind of security dilemma that can be created by determined but marginal spoilers in ethnic conflicts. Despite the reality that in the 1990s most Kosovar Albanians did not seem enthusiastic about a violent confrontation with the Serbs, the KLA's tactics were able to precipitate Serbian reprisals, which in turn triggered a humanitarian response by NATO. To be sure, the Serbs could have probably deflated the KLA's strategy by being more conciliatory and accommodating to Kosovar Albanian political moderates like Rugova. But given both the KLA's violent tactics and NATO's escalating threats, Milošević probably calculated that any concessions to Kosovar Albanians would be construed as weakness by his domestic audience. Similarly, in the face of Serbian reprisals, Rugova, who had been a long-time advocate of peaceful negotiation, would probably have found it hard to respond to any peace gesture that would have Kosovar Albanians give up their demands for greater autonomy. In the end, the KLA's tactics probably widened the gulf between both sides of the crisis and made a peace settlement much harder to achieve.

\section{IV \\ EMPIRICAL CHALLENGES}

To be sure, humanitarian interventions can have unintended and perverse effects. But where humanitarian intervention might cause some atrocities, but might also prevent others, what are its net effects on the overall level of atrocities?

There is probably not an easy answer to this question because it is difficult to determine a priori those humanitarian atrocities that never occurred because of the plausible threat of a humanitarian intervention. One might try to isolate circumstances where atrocities have already begun before humanitarian intervention occurred, and ask how intervention affected the level of atrocities. But such an analysis would still be affected by selection bias. For instance, one might argue that for dominant groups that are particularly sensitive to military retaliation by the international community, even a marginal increase in the risk of intervention might be sufficient to deter them from committing atrocities.

One possible solution would be to isolate all instances where a civil war or significant rebellion has taken place, and ask why atrocities took place in certain contexts and not others. The problem with such an approach, however, is that because the threat of some form of external intervention is presumably

145. See id. at 241; Joanne Mariner, Findlaw Forum: Kosovo's Unquiet Dead, CNN.COM, June 20, 2001, available at http://www.cnn.com/2001/LAW/06/columns/fl.mariner.kosovo.06.20/. 
present in all civil wars, it would prove ultimately difficult to attribute any decision by a perpetrator whether to commit atrocities to the risk of provoking a humanitarian intervention. Moreover, the prospect of humanitarian interventions might have indirect effects on the decision by oppositional groups to embark on civil wars and rebellions in the first place. For instance, certain minority or subordinate groups that have strong strategic ties with third-party states might find it unnecessary to initiate rebellions as a means to achieve political goals, thereby making it less likely that such a group will be involved in a civil war. Of course, the dynamic could cut both ways: certain groups might be more willing to initiate civil wars and rebellions if they believe that downstream intervention by third-party states will make it more likely that they will be able to extract important concessions from the dominant groups.

In sum, because the empirical question of the net effects of humanitarian interventions is plagued by uncertainty, it would be premature to assume that either dramatically expanding or reducing the number of interventions would be beneficial. ${ }^{146}$ But are there legal or other strategic policy changes to the current humanitarian intervention regime that might alleviate some of its perverse effects? Are there ways the international community might continue to engage in humanitarian interventions without undermining the possible benign effects of such interventions? Part V discusses several legal and political changes to the current humanitarian regime that might mitigate some of the regime's perverse effects.

\section{$\mathrm{V}$ \\ NORMATIVE RECOMMENDATIONS}

What legal and political changes would mitigate some of the unintended effects of humanitarian interventions on the overall level of atrocities? This Part argues that the humanitarian intervention regime should try to adopt some comparative fault principles from the U.S. corrective justice framework. Part A suggests that the international community could try to reduce the benefits to rebel leaders of humanitarian intervention when such leaders have engaged in provocative behavior against dominant groups, which is how a comparative

146. Some commentators have argued that interventions that focus on stopping perpetrators tend to decrease the severity of mass atrocities. See Matthew Krain, International Intervention and the Severity of Genocides and Politicides, 49 INT'L STUD. Q. 363 (2005) (providing empirical data to support such a relationship). But such studies do not address the moral hazard problem we have identified, which involves the risk that the prospect of intervention might lead rebel leaders to engage in high-risk or provocative behavior against dominant groups in the first place. In other words, it will be difficult to make any conclusive empirical generalizations about the net effect of humanitarian interventions on the level of atrocities unless one can also isolate the risks that humanitarian interventions might actually cause some atrocities. Indeed, Krain seems to assume away the possibility that humanitarian interventions could have any effect on the strategy of rebel leaders. See id. at 365 ("[A]ny attempt to understand how intervention might affect the severity of genocides or politicides must focus on the intervention's effect on the perpetrator rather than multiple sides in a conflict."). 
fault mechanism works in the domestic torts regime. Part B suggests that another approach would be to allow the rebel leaders' provocative behavior to absolve perpetrators from certain sanctions and prosecutions by international criminal tribunals, which is partly how the defense of provocation works in domestic criminal law.

\section{A. Applying Comparative Fault Principles to Interventions}

One way to discourage rebel leaders from engaging in provocative behavior against dominant groups is to adopt a comparative fault approach that would limit the political and economic benefits rebel leaders stand to gain from humanitarian interventions. Evidence of a systematic and continuous pattern of provocative behavior against a dominant group could be treated as a proximate cause of any resultant humanitarian crisis, which would result in a reduction of benefits to the victim groups. The implicit assumption in this framework is that both the rebel leaders and the perpetrators would be jointly responsible for the resultant harm to the victims and the relevant humanitarian intervention regime would try to ensure that both groups internalize the costs of their actions. ${ }^{147}$ of course, the international community might decide to apply appropriate evidentiary principles in making judgments as to whether any provocative behavior by a victim group was a proximate cause of any particular atrocity, including possibly requiring that the various incidents have some temporal proximity to the alleged provocative behavior.

The comparative fault principle in a humanitarian intervention context could work in one of two ways: (1) the imposition of lustration against the rebel leaders upon the successful completion of a humanitarian intervention; (2) the refusal of the international community to impose (or force) any political solution to the underlying conflict that gave rise to the atrocities. In both scenarios, the proportionality of the dominant group's response to the provocation would be a factor in determining how significantly the international community should reduce the benefits to the rebel groups. For instance, a grossly disproportionate retaliation by the dominant group might warrant an intervention that specifically gives military leverage to the rebel group.

In the case of lustration, rebel leaders who expect that a humanitarian intervention will help them secure a favorable power-sharing arrangement with the dominant group would be out of luck. ${ }^{148}$ Any such lustration principle

147. For an argument that a properly calibrated comparative negligence regime would provide the best incentives to both victims and injurers in a tort scheme to take optimal precautions, see Ezra Friedman, The Robust Efficiency of Comparative Negligence (Oct. 22, 2007) (unpublished article, on file with the author).

148. Lustration, which commonly involves barring individuals implicated in past crimes and atrocities from holding public office, is a very common transitional justice instrument. For a discussion of lustration laws in post-Cold War Europe, see Roman David, Lustration Laws in Action: The Motives and Evaluation of Lustration Policy in the Czech Republic and Poland 
would also preclude the transfer of economic resources or any territorial concessions to the rebel leaders or to the victim groups generally, but would not necessarily preclude efforts by the international community to engage in rehabilitation efforts that narrowly target injured victims. The international community could invest resources in addressing specific harms suffered by the victims of mass atrocities, but avoid any efforts which are likely to resolve the underlying conflict in favor of the rebel groups. Such a narrow application of the lustration sanction would be in accord with comparative fault principles suggesting not that the victims should be barred completely from recovery, but that their recovery should be reduced based on their level of fault. ${ }^{149}$

Of course, lustration by itself will not necessarily provide the optimal division of liability between the perpetrators and the rebel leaders. For example, a blanket lustration regime that targets all rebel leaders who engage in provocative behavior will not account for the fact that different rebel leaders exercise varying levels of precautions across different conflicts. But no existing comparative fault regime in the domestic torts context appears to calibrate the distribution of liability (or responsibility) between the tortfeasor and victims in a precise manner. ${ }^{150}$ In any event, while less than an ideal outcome, lustration seems better than the status quo in which rebel leaders usually gain significant political benefits in the wake of a humanitarian intervention.

Similarly, when the international community intervenes in civil wars where rebel leaders have engaged in provocative behavior against dominant groups, it should not attempt to force (or encourage) the parties to negotiate a long-term political solution to the conflict. The international community should not be in the business of helping the combatants settle their own disputes, especially when one side might lack the resources or resolve to reach a favorable settlement in the absence of humanitarian intervention. Otherwise, the international community will simply become a pawn in the rebel leader's strategy to extract favorable political concessions from the dominant group.

The problem is that when rebel leaders fail to bear ultimate responsibility for prosecuting their claims through the use of force, they have an incentive to free-ride off the efforts of third parties who intervene in the conflict. In this context, the intervention of third-party states obscures the real risks and costs associated with initiating a high-stakes rebellion. The domestic torts regime

(1989-2001), 28 Law \& Soc. InQuiRy 387 (2003); see also Mark S. Ellis, Purging the Past: The Current State of Lustration Laws in the Former Communist Bloc, 59 Law \& ContemP. Probs. 181,181 (1997).

149. See Friedman, supra note 147, at 5 (suggesting that the optimal comparative fault regime for negligence would increase the relevant party's share of liability with that party's carelessness).

150. See id. at 9 ("One significant difficulty with applying a comparative negligence rule is that it requires juries and judges to quantify the amount by which each party was negligent ... Without specific guidelines for allocating shares of negligence, any division is at best subjective if not arbitrary."). 
deals with this free-riding risk by imposing on the victim the responsibility of litigating her own tort claims. By denying or limiting relief to rebel leaders who attempt to capitalize on outside intervention, the international community will encourage rebel leaders to only initiate rebellions that are cost-effective and that have a plausible chance of success without third-party intervention. Put differently, a comparative fault regime will discourage rebel leaders from redistributing the risks of suicidal rebellions to the international community.

Finally, a humanitarian regime based on comparative fault principles would be consistent with the emerging international law norm of the responsibility to protect. While the scope of this new international norm is unclear, and it is still questionable whether it is an international norm at all, the U.N. Outcome Document discussing the norm makes it clear that the primary responsibility of protecting individuals from humanitarian atrocities still resides in the state in which such atrocities take place, ${ }^{151}$ and that the international community only has the residual responsibility to use both peaceful and other humanitarian means to help protect populations from atrocities when the host state has failed to act. By suggesting that the primary obligation resides primarily with the state in which atrocities take place, the U.N. Outcome Document implicitly recognizes that the relevant groups engaged in a civil war have the responsibility to take precautions to make sure their followers are not harmed. ${ }^{152}$ A comparative liability regime would give the combatants the incentives to take these responsibilities seriously.

An alternative strategy for reducing these unintended effects is for the international community to adopt more rigorous criteria in deciding when to intervene. ${ }^{153}$ The international community could try to screen out opportunistic rebellions and only provide humanitarian relief when there is evidence that the rebels have a reasonable chance to obtain concessions by force of arms against the dominant group in the absence of intervention. In theory, the classic international law principles governing belligerents were supposed to serve as such a screening device. These principles recognized that external interventions in support of budding rebellions could lead to widespread internal instability, increased communal violence, and a possible breakdown of the state itself. Thus, third parties were not permitted under international law to recognize rebels on equal terms with the state in a civil war until the rebels had acquired

151. See Responsibility to Protect, supra note 3, XI (2001) (Synopsis 1(a)) ("State sovereignty implies responsibility, and the primary responsibility for the protection of its people lies with the state itself.").

152. Of course, this obligation rests formally with the state, but in civil conflicts where the state is weak, rebel leaders ostensibly act as sovereign elements in their territories.

153. Indeed, one way insurance companies deal with this problem is that they tend to raise the insurance premium significantly whenever they think there is a high risk of moral hazard. See Jonathan R. Macey, Commercial Banking and Democracy: The Illusive Quest for Deregulation, 23 YALE J. ON REG. 1 (2006) (discussing regulatory schemes that link political insurance premiums with moral hazard risks). 
substantial territory by force of arms and attained belligerent status. ${ }^{154}$ Without demonstrating to the international community that they had both widespread support and the resources to wage war effectively against the state, rebels would be denied all the courtesies and privileges accorded to legal combatants, including the possibility of external military assistance. ${ }^{155}$ Indeed, even when rebels had attained the status of belligerents, third parties who wished to remain neutral could not lend any assistance to either side. ${ }^{156}$ Today, these international principles governing belligerents have become obsolete as both strategic and humanitarian third-party interventions have become the norm.

\section{B. Allowing a Partial Defense of Provocative Rebellion}

Perpetrators of atrocities are routinely subject to a range of sanctions imposed by the international community, including economic boycotts, travel bans, financial account freezes, and prosecutions by international criminal tribunals. ${ }^{157}$ Some of these sanctions can be imposed in the absence of humanitarian intervention, but others, such as when perpetrators from dominant groups are indicted and tried before international criminal tribunals, are usually imposed only after intervention has taken place. But the international community could allow a provocation defense that would reduce such sanctions. As in the domestic criminal context, the international community could recognize a defense of deliberate provocation by victims (or rebel

154. Lassa P. Oppenheim observes that a legal belligerent had to meet four conditions to qualify for treatment as a legal combatant:

[T] he existence of a civil war accompanied by a state of general hostilities; occupation and measures of orderly administration of a substantial part of national territory by the insurgents; observance of the rules of warfare on the part of the insurgent forces acting under a responsible authority; the practical necessity for third States to define their attitude to the civil war.

Lassa P. OpPenheim, 2 International Law $\$ 76$ (Sir Hersch Lauterpacht ed., 7th ed. 1952); see also Yair M. Lootsteen, The Concept of Belligerency in International Law, 166 MiL. L. Rev. 109,114 (2000) (discussing how the law of belligerency applies to armed conflicts under international law and the importance of holding territory); David Wippman, Change and Continuity in Legal Justifications for Military Intervention in Internal Conflict, 27 Colum. Hum. RTS. L. REv. 435, 440 (1996) (arguing that military intervention in support of rebels interferes with a state's internal affairs). Indeed, the U.S. Supreme Court applied the belligerency test to Confederate rebels during the American Civil War. See The Prize Cases, 67 U.S. (2 Black) 635, 666-67 (1863) ("When the party in rebellion occupy and hold in a hostile manner a certain portion of territory; have declared their independence; have cast off their allegiance; have organized armies; have commenced hostilities against their former sovereign, the world acknowledges them as belligerents, and the contest a war.").

155. See Robert W. Gomulkiewicz, International Law Governing Aid to Opposition Groups in Civil War: Resurrecting the Standards of Belligerency, 63 WASH. L. REv. 43, 56 (1988) (discussing the belligerency standard in international law).

156. See Wippman, supra note 154 , at 442 (observing that those who wish to remain neutral could not assist either side in the conflict).

157. For a detailed analysis of the prosecution of perpetrators before international criminal tribunals, see Mark A Drumbl, Atrocity, Punishment, and International LaW 46-66 (2007). 
leaders) that would mitigate the sanctions faced by the perpetrator of atrocities. Of course, the proportionality of the dominant group's response to the provocation should be a factor in deciding the appropriate level of punishment for perpetrators.

Although criminal sanctions in the domestic context tend to focus exclusively on perpetrators' incentives, many commentators have observed that criminal law applies a version of the relative fault principle from torts when it partially absolves perpetrators from punishment based on the victims' provocative behavior. ${ }^{158}$ For instance, the defense of provocation or "heat of passion," which is available in all jurisdictions in the United States, downgrades an offense of murder to manslaughter when the defendant can prove that he killed another in the heat of passion after a provocation. ${ }^{159}$

Typically, commentators have justified the provocation defense as either a partial excuse or a partial justification, but more recently, law and economics scholars have suggested that the defense not only provides the correct incentives for the potential perpetrator but also for the potential victim. ${ }^{160}$ The defense might affect the incentives of the victim to engage in provocative behavior through two different mechanisms. First, it might do so directly by decreasing the vindictive pleasure that victims might get from seeing their perpetrators punished. ${ }^{161}$ Second, it might do so indirectly because perpetrators will be less inclined to target victims who take appropriate precautions and do not engage in provocative behavior. ${ }^{162}$ Potential victims will have an incentive to take greater precautions if they know they are less likely to be targeted by perpetrators.

In any event, one need not subscribe to such accounts of victim motivation in a domestic context to see that reducing sanctions targeted at perpetrators will likely affect the incentives of victims in a humanitarian crisis. Unlike domestic victims in a criminal context, victims facing atrocities in a civil war stand to gain more than "vindictive" benefits from the suffering of their perpetrators. Because the perpetrators and victims of atrocities are usually

158. Omri Ben-Shahar \& Alon Harel, The Economics of Criminal Law Attempts, 145 U. PA. L. REv. 299, 317 (1996) ("Mitigating the punishment for offenders who commit homicide as a result of provoked, uncontrollable passion provides incentives to potential victims to abstain from provocative behavior."); Alon Harel, Efficiency and Fairness in Criminal Law: The Case for a Comparative Law Principle of Comparative Fault, 82 CALIF. L. Rev. 1181, 1216 (1994) ("A legal system in which provocation functions as a partial defense provides incentives both for the potential victim to avoid provocation (by reducing the punishment levied on persons who commit homicide as a result of provocation) and for the person who considers committing homicide to avoid carrying it out (by imposing criminal sanctions upon him).").

159. See Harel, supra note 158, at 1213-1217.

160. See Ben-Shahar \& Harel, supra note 158, at 316-18.

161. See id.; see also Kenworthey Bilz, The Puzzle of Delegated Revenge, 87 B.U. L REv. 1059, 1062 (2007) ("[V]ictims regard punishment [by the state] as an important device for restoring losses to their self worth and status.").

162. See id. 
also political and military adversaries, any outside sanctions targeted at perpetrators will tend to translate to concrete benefits to the victims and their leaders. In the zero-sum world in which many of these rebellions take place, any outside sanctions inflicted against a dominant group increase the chance-even if marginally - that the dominant group will eventually make some sort of concession to the rebels.

Pursuing this incentive-based analysis a little further, victims of atrocities would likely be more motivated than domestic victims of crime to internalize the costs of provocative behavior if they are aware that such behavior will reduce the sanctions targeted at perpetrators. Unlike punishment in the domestic criminal context, sanctions targeted at perpetrators of atrocities may for all intents and purposes be treated as a form of tort-like compensation for victims. We have now come almost full circle in our analysis: in the current humanitarian intervention regime, sanctions targeted against a perpetrator are likely to present the same kinds of moral hazard risks as other forms of political benefits that victim groups gain from intervention that do not account for the relative fault of the victim group's leaders.

Turning to the perpetrators of atrocities, reducing external sanctions based on the level of provocation can also positively influence the manner in which perpetrators choose targets of atrocities. If the harshest sanctions are only imposed on perpetrators who target victims who have not engaged in provocative behavior, then future perpetrators might be deterred from targeting such victims. But if the international community imposes the harshest sanctions against perpetrators regardless of the provocative behavior of the victims, then the perpetrator has an incentive to inflict the harshest level of atrocities against any rebel group (or noncombatants from such a group) regardless of the rebel group's behavior. Thus, disregarding the provocative behavior of victims in a sanctions regime raises the familiar problem posed by marginal deterrence. As a noted economist puts it, "If the thief has his hand cut off for taking five dollars, he had just as well take $\$ 5,000 . " 163$ The intuition is that we should discourage perpetrators from committing atrocities on an even larger scale because of a failure to distinguish between the sanctions targeting two offenses of different magnitude. ${ }^{164}$ In this case, one might argue that mass killings targeted at a victim group that has engaged in provocative behavior are of a different magnitude from mass killings targeted at a victim group that has not.

Even more than in the domestic criminal law context, there is probably a need to apply relative fault principles when deciding which kinds of sanctions to mete out against perpetrators of humanitarian atrocities. Both as a means of

163. See George J. Stigler, The Optimum Enforcement of Laws, 78 J. PoL. EcoN. 526, 527 (1970).

164. See Dan M. Kahan, Response: Between Economics and Sociology: The New Path Of Deterrence, 95 MiCH. L. REv. 2477 (1997) (discussing the role of marginal deterrence in criminal law); Neal Kumar Katyal, Deterrence's Difficulty, 95 Mich. L. Rev. 2385 (1997) (same). 
discouraging victims from engaging in high-risk behavior and for discouraging perpetrators from committing the most egregious atrocities regardless of how badly the victims act, it makes sense to implement a system of escalating sanctions based on the level of provocation by the victim.

\section{CONCLUDING THOUGHTS: IS THERE A ROLE FOR THE INTERNATIONAL CRIMINAL COURT?}

Under the relative fault scheme, this Article argues that adjusting the benefits available to victims and the sanctions targeted at perpetrators can influence the victims to take adequate precautions to avoid atrocities and discourage perpetrators from engaging in the most heinous atrocities. In large part, this approach expands on the retributive and deterrent framework of the humanitarian intervention regime that focuses on perpetrators and extends that framework to the provocative behavior of rebel leaders in the context of a civil war or rebellion.

This framework raises an obvious question concerning a possible role for the International Criminal Court. If the International Criminal Court can be used as an instrument to influence the incentives of perpetrators, why can it not be used to target rebel leaders who engage in provocative acts that instigate atrocities? In other words, instead of recalibrating the sanctions targeting perpetrators and the benefits available to victims from humanitarian interventions, why not haul the rebel leaders who engage in provocative behavior before the International Criminal Court?

An exploration of the merits and the scope of the International Criminal Court, and of its possible effects on the behavior of perpetrators or victims, is beyond the scope of this Article. Suffice it to observe that various commentators have not only questioned the deterrent effects of international criminal tribunals generally, ${ }^{165}$ but have also raised concerns as to whether these tribunals might actually exacerbate the level of humanitarian atrocities. ${ }^{166}$ But setting aside for now these significant criticisms, there are additional reasons why prosecution by an international criminal tribunal would not be an appropriate mechanism for addressing provocative behavior by rebel groups in

165. See DrumBL, supra note 157, at 169-73 (questioning the deterrent effect of international criminal tribunals); William W. Burke-White, Complementarity in Practice: The International Criminal Court as a Part of a System of Multi-Level Global Governance in the Democratic Republic of Congo, 18 LEIDEN J. INT'L L. 557, 587 (2005) (observing the methodological difficulties with trying to show that international criminal tribunals deter atrocities).

166. Julian Ku \& Jide Nzelibe, Do International Criminal Tribunals Deter or Exacerbate Humanitarian Atrocities?, 84 WASH U. L. REv. 777 (2006) (suggesting that evidence that perpetrators already face preexisting sanctions that are more severe and certain than those meted out by international criminal tribunals undermines claims that those tribunals will have a deterrent effect); Jack Snyder \& Leslie Vinjamuri, Trial and Error: Principle and Pragmatism in Strategies of International Justice, 28 INT'L SEC. 5, 6 (2004) (expressing doubt over the deterrent effects of international criminal tribunals and suggesting that they make peace settlements more difficult). 
the context of a civil war or rebellion.

First, many, if not most, provocative actions by rebel leaders will likely fall short of qualifying as crimes that fall under the jurisdiction of the International Criminal Court and virtually all ad hoc international criminal tribunals. For instance, the Rome Treaty, which establishes the International Criminal Court, makes it clear that its jurisdiction is limited to "the most serious crimes of concern to the international community as a whole." 167 Specifically, these serious crimes of concern have included: "War Crimes," "Crimes Against Humanity," "Genocide," and "Aggression."168 While the first three crimes are relatively uncontroversial and are proscribed by the Geneva Convention, ${ }^{169}$ member states have yet to agree to what kinds of actions would constitute an act of aggression; so presumably, that crime is still outside the International Criminal Court's jurisdiction until member states can reach an acceptable definition. ${ }^{170}$ In any event, the relevant crimes usually have to occur during a war and involve systematic attacks against civilian populations, which would probably exclude much of the provocative behavior by rebel leaders. ${ }^{171}$

Second, investigations and prosecutions by international criminal tribunals are both relatively expensive and politically controversial. It is also unlikely that the international community has either the political will or the resources to extend the jurisdiction of these tribunals to a new category of crimes involving provocative rebel leaders. For instance, the International Tribunal for Rwanda has tried only twenty-six individuals in its seven-year existence (at a cost of

167. Rome Statute of the International Criminal Court, art. 5.1, U.N. Doc. A/CONF.183/9 (July 17, 1998) [hereinafter Rome Statute].

168. See id. art. 5.1(a)-(d).

169. Michael O'Donovan, Criminalizing War: Toward a Justifiable Crime of Aggression, 30 B.C. INT'L \& Comp. L. REv. 507, 507-08 (2007) ("The inclusion of the first three crimes was undisputed. The crime of aggression, however, was highly controversial, and remains divisive today. Unlike the first three crimes, the crime of aggression implicates not only individual responsibility, but state responsibility as well."). Even the definition of the more widely accepted category of "crimes against humanity" has been subject to controversy. See Beth Van Schaack, The Definition of Crimes Against Humanity: Resolving the Incoherence, 37 CoLum. J. Transnat'L L. 787 (1999).

170. Alberto L. Zuppie, Aggression as International Crime: Unattainable Crusade or Finally Conquering the Evil?, 26 PENN ST. INT'L L. REv. 1 (2007) (discussing difficulties with international efforts to define the contours of the crime of aggression); see also Grant M. Dawson, Defining Substantive Crimes Within the Subject Matter Jurisdiction of the International Criminal Court: What Is the Crime of Aggression?, 19 N.Y.L. ScH. J. INT'L \& CoMP. L. 413, 419-420 (2000) (discussing how the Preparatory Commission has been charged with finding a definition but does not have one yet.).

171. See Sonja Starr, Extraordinary Crimes at Ordinary Times: International Justice Beyond Crisis Situations, 101 NW. U. L. REv. 1257, 1269 (2007) (observing that the focus of these international crimes is on civilian deaths during a crisis or wartime). The treaties establishing the various international criminal tribunals tended to limit their jurisdiction to atrocities targeting civilian populations. For instance, Article 7.1 of the Rome Statute states: "For the purpose of this Statute, 'crime against humanity' means any of the following acts when committed as part of a widespread or systematic attack directed against any civilian population, with knowledge of the attack." Rome Statute, supra note 167, art. 7.1 (emphasis added). 
one billion dollars) and only has twenty-six trials under way. ${ }^{172}$ Part of the problem is that these tribunals often have to pursue investigations and gather evidence and testimony from witnesses and places located thousands of miles from where the tribunals sit. In any event, both the international community and leading international law publicists seem to be wary of the high costs of delivering justice through these tribunals. ${ }^{173}$ Recent developments suggest that it is unlikely that the international community will be willing to extend the jurisdiction of these tribunals to prosecuting rebel leaders who engage in provocative activity. Indeed, escalating costs at the International Criminal Tribunals for the former Yugoslavia and Rwanda have already prompted the U.N. Security Council to pass resolutions calling for those bodies to stop issuing new indictments and wrap up all operations by $2010 .{ }^{174}$ Finally, and more importantly, both the United States and China still refuse to accede to the Rome Treaty, which casts doubt on the ability of the International Criminal Court to carry out its current limited mandate effectively. ${ }^{175}$

172. President of International Criminal Tribunal for Rwanda, Completion Strategy of International Tribunal for Rwanda, Letter of December 5, 2005, addressed to the President of the Security Council, Annex 1, U.N. Doc. S/2005/782 (Dec. 14, 2005), available at http://69.94.11.53/ENGLISH/completionstrat/s-2005-782e.pdf.

173. See, e.g., Jose E. Alvarez, Crimes of State/Crimes of Hate: Lessons from Rwanda, 24 YALE J. INT'L L. 365 (1999) (observing that enormous amount of money expended on the International Criminal Tribunal for Rwanda would have been better spent developing better domestic criminal accountability in Rwanda).

174. S.C. Res. 1534 , ๆ 3, U.N. Doc. S/RES/1534 (Mar. 26, 2004); S.C. Res. 1503, ๆ 7, U.N. Doc. S/RES/1503 (Aug. 28, 2003).

175. See Jack Goldsmith, The Self-Defeating International Criminal Court, 70 U. CHI. L. REv. 89, 93 (2003); see also John R. Bolton, The Risks and Weaknesses of the International Criminal Court from America's Perspective, 64 LAW \& ConTEMP. ProBs. 167 (2001); Michael Smidt, The International Criminal Court: An Effective Means of Deterrence?, 167 MiL. L. REv. 156 (2001); Ruth Wedgwood, Fiddling in Rome, 77 ForEIGN AFF. 20 (1998). Jenia Iontcheva has also argued that the lack of support for the ICC from key players such as the United States suggests that a less-centralized approach to criminal enforcement might be appropriate. See Jenia Iontcheva, Nationalizing International Criminal Law, 41 STAN. J. INT'L L. 1, at 10-15 (2005). Posner and Yoo have argued that United States withdrawal from the ICC reflects the unwillingness of the United States to be subject to an entity it could not control. See Eric A. Posner \& John C. Yoo, Judicial Independence in International Tribunals, 93 CALIF. L. Rev. 1, 67-70 (2005). For a comprehensive discussion of the U.S. approach to the ICC negotiations during the Clinton Administration, see David J. Scheffer, Staying the Course with the International Criminal Court, 35 CORNELL. INT'L L.J. 47 (2002). 